\title{
A case of extreme particulate matter concentrations over Central Europe caused by dust emitted over the southern Ukraine
}

\author{
W. Birmili ${ }^{1}$, K. Schepanski1 ${ }^{1,2}$, A. Ansmann ${ }^{1}$, G. Spindler ${ }^{1}$, I. Tegen ${ }^{1}$, B. Wehner $^{1}$, A. Nowak ${ }^{1}$, E. Reimer ${ }^{3}$, I. Mattis ${ }^{1}$, \\ K. Müller ${ }^{1}$, E. Brüggemann ${ }^{1}$, T. Gnauk ${ }^{1}$, H. Herrmann ${ }^{1}$, A. Wiedensohler ${ }^{1}$, D. Althausen ${ }^{1}$, A. Schladitz ${ }^{1}$, T. Tuch ${ }^{1,4}$, \\ and G. Löschau ${ }^{5}$ \\ ${ }^{1}$ Leibniz Institute for Tropospheric Research, Leipzig, Germany \\ ${ }^{2}$ Leibniz Institute of Marine Sciences, IFM-GEOMAR, Kiel, Germany \\ ${ }^{3}$ Institut für Meteorologie, Freie Universität Berlin, Germany \\ ${ }^{4}$ Helmholtz Center for Environmental Research, Leipzig, Germany \\ ${ }^{5}$ Sächsisches Landesamt für Umwelt und Geologie, Dresden, Germany
}

Received: 12 July 2007 - Published in Atmos. Chem. Phys. Discuss.: 20 August 2007

Revised: 24 January 2008 - Accepted: 24 January 2008 - Published: 26 February 2008

\begin{abstract}
On 24 March 2007, an extraordinary dust plume was observed in the Central European troposphere. Satellite observations revealed its origins in a dust storm in Southern Ukraine, where large amounts of soil were resuspended from dried-out farmlands at wind gusts up to $30 \mathrm{~m} \mathrm{~s}^{-1}$. Along the pathway of the plume, maximum particulate matter $\left(\mathrm{PM}_{10}\right)$ mass concentrations between 200 and $1400 \mu \mathrm{g} \mathrm{m}^{-3}$ occurred in Slovakia, the Czech Republic, Poland, and Germany. Over Germany, the dust plume was characterised by a volume extinction coefficient up to $400 \mathrm{Mm}^{-1}$ and a particle optical depth of 0.71 at wavelength $0.532 \mu \mathrm{m}$. In-situ size distribution measurements as well as the wavelength dependence of light extinction from lidar and Sun photometer measurements confirmed the presence of a coarse particle mode with diameters around 2-3 $\mu \mathrm{m}$. Chemical particle analyses suggested a fraction of $75 \%$ crustal material in daily average $\mathrm{PM}_{10}$ and up to $85 \%$ in the coarser fraction $\mathrm{PM}_{10-2.5}$. Based on the particle characteristics as well as a lack of increased $\mathrm{CO}$ and $\mathrm{CO}_{2}$ levels, a significant impact of biomass burning was ruled out. The reasons for the high particle concentrations in the dust plume were twofold: First, dust was transported very rapidly into Central Europe in a boundary layer jet under dry conditions. Second, the dust plume was confined to a relatively stable boundary layer of $1.4-1.8 \mathrm{~km}$ height, and could therefore neither expand nor dilute efficiently. Our findings illustrate the capacity of combined in situ and remote sensing measurements to characterise large-
\end{abstract}

Correspondence to: W. Birmili (birmili@tropos.de) scale dust plumes with a variety of aerosol parameters. Although such plumes from Southern Eurasia seem to occur rather infrequently in Central Europe, its unexpected features highlights the need to improve the description of dust emission, transport and transformation processes needs, particularly when facing the possible effects of further anthropogenic desertification and climate change.

\section{Introduction}

\subsection{Wind-blown dust and climate}

Wind-blown dust particles emitted from dry soil surfaces contribute considerably to the global aerosol mass and optical thickness, as well as to particle concentrations near the surface. With the exception of sea salt particles, soil dust contributes globally to the highest atmospheric mass load of all aerosol particle types (Textor et al., 2006). Dust particles are part of the coarse mode aerosol typically occurring in the super- $\mu \mathrm{m}$ size range (Haywood et al., 2001; Reid et al., 2003). Current estimates of annual global emission of dust particles that are available for long-range transport vary between 1000 and $2000 \mathrm{Tg}$ (Zender et al., 2004).

Frequent transport of dust plumes from the Sahara, the largest dust source worldwide, towards Europe can be observed frequently within the free troposphere (Ansmann et al., 2003; Barkan et al., 2005; Amiridis et al., 2005). Other sources of mineral dust aerosol include the Arabian Peninsula, the Gobi and Taklamakan deserts in Asia, and the Australian and South American deserts (Prospero et al., 2002).

Published by Copernicus Publications on behalf of the European Geosciences Union. 
Atmospheric dust may affect regional climates directly and indirectly by influencing incoming and outgoing solar radiation, modifying cloud properties and precipitation formation, and affecting chemical processes in the atmosphere. The direct radiative forcing at the top-of-atmosphere by the enhancement of dust aerosol from anthropogenic land use modifications is estimated to range between $-0.3 \mathrm{~W} \mathrm{~m}^{-2}$ and $+0.1 \mathrm{~W} \mathrm{~m}^{-2}$, assuming that $20 \%$ of the atmospheric dust originates from soil surfaces disturbed by anthropogenic activities like cultivation (Solomon et al., 2007). Radiative forcing by dust not only impacts the radiation balance of the Earth directly, but also influences the energy distribution within the atmosphere. As a consequence, the presence of dust may weaken the hydrological cycle (Miller et al., 2004).

In addition to the direct radiative effect, aerosol particles also influence the formation and lifetimes of clouds, although the role of soil dust particles in these processes remains uncertain. The coating of dust by soluble species enhances their ability to form cloud condensation nuclei (CCN) (Wurzler et al., 2000), while uncoated dust particles can enhance the formation of ice clouds (Ansmann and Müller, 2005). Asian dust transported to areas affected by high levels of anthropogenic pollution is in particular impacting on atmospheric chemistry (Krueger et al., 2004; Wang et al., 2007) because sulfate and nitrate species efficiently react on the surface of the calcite-rich dust particles. Dust may also play an important role in ozone chemistry (Bonasoni et al., 2004). Changed meteorological conditions as consequence of climate change are expected to influence dust production and transport, with increasing atmospheric dust loads and radiative forcing in drier climates Woodward et al. (2005). The magnitudes of the radiative forcing (direct and indirect) by dust depend on mineralogical, chemical and optical particle properties as well as on the vertical extent of the dust plumes in the atmosphere (Sokolik et al., 2001; Satheesh and Moorthy, 2005). A significant uncertainty factor in quantifying dust fluxes is the lack of knowledge about emission potentials of different source areas Harrison et al. (2001).

Dust emissions are anticipated to change under changed climate conditions due to alterations in both natural vegetation growth and cultivation patterns, as well as changes in transport pathways (Mahowald and Luo, 2003; Tegen et al., 2004; Woodward et al., 2005). Assessments of the role of dust in a different climates require the understanding of the controls on dust emission, including the role of changes in land use. Importantly, human activities can modify dust emissions from soils by changing the availability of fine particles, e.g., through destruction of soil crusts and removal of vegetation in semi-arid regions. The total amount of soil dust emission from such anthropogenic influence are currently estimated to contribute up to $20 \%$ of the total dust emissions (Solomon et al., 2007). However, such estimates are highly uncertain, as there are currently no appropriate measurements for quantifying large-scale dust emission fluxes.

\subsection{Dust activation}

Unvegetated areas containing fine and loose sediments can be sources of dust particle emission when strong surface winds occur. The Sahara is the most important source for soil dust worldwide; it is estimated to be responsible for $50 \%$ or more of the global atmospheric dust load (Goudie and Middleton, 2001). Ground dusts are mainly emitted via the process of saltation (Gillette, 1978; Shao et al., 1993; Marticorena and Bergametti, 1995), where sand particles that are easily lifted from the surface impact on the ground. The release of kinetic energy breaks the binding of finer soil particles like clay, which are then available for long-range transport. In some instances direct particle lifting has also been observed (Loosmore and Hunt, 2000), but this process is usually only of local importance. Generally, strong winds are required to initiate and sustain dust emission from soils. These are often related to convective systems or the passages of cold fronts (Pye, 1987; Shao, 2000). Dust injected into high atmospheric levels of up to several kilometers can be transported over horizontal distances of thousands of kilometers in strong wind systems (Alpert et al., 2004).

Dust emissions are particularly strong in areas that contain fine and loose sediments. A good agreement has been found between the maximum occurrence of dust over land surfaces observed by satellites and the location of enclosed topographic depressions where fine sediments may have accumulated during the past (Prospero et al., 2002). The emission strength in a potential source region depends on surface properties like the aerodynamic surface roughness length, as structural elements like rocks or vegetation increase the transport of wind energy to the surface, but also partly absorb this energy, increasing the threshold wind friction velocity required for dust emission (Marticorena and Bergametti, 1995). The presence of crusts can reduce dust emission from a soil surface (Belnap and Gillette, 1997). The loss of fine soil material by wind deflation can lead to a decrease of dust production from a specific area over time (Gillette and Chen, 2001). Surface disturbances as a consequence of cultivation of soils in dry regions may lead to enhanced dust emissions. In agricultural soils, particle mass fluxes depend on, among other parameters, soil wetness, plant growth, field size, and wind direction at field scales (Donk and Skidmore, 2003; Hagen, 2004).

\subsection{Legal limit values for $\mathrm{PM}_{10}$}

Since 2005, legal limit values apply to environmental particulate matter (PM) within the European Community (Air Quality Framework Directive (96/62/EC) and First Air Quality Daughter Directive (1999/30/EC)). Here, PM $_{10}$ denotes the total mass concentration of suspended particles with aerodynamic diameters smaller than $10 \mu \mathrm{m}$. In practice, exceedances of the legal limit values, particularly the daily limit value of $50 \mu \mathrm{g} \mathrm{m}^{-3}$ have occurred at air quality monitoring 
stations in many EU member states frequently, and health scientists have called for a more serious consideration of efficient abatement measures (Annesi-Maesano et al., 2007). The actual reasons for the $\mathrm{PM}_{10}$ exceedances are manifold, and may vary from region to region.

In the UK, which may be taken as representative for Western Europe, the advection of continental air masses as well as regional secondary aerosol formation seem to be responsible for the majority of exceedances (Charron et al., 2007). In the metropolitan area of Berlin, Germany, $50 \%$ of the $\mathrm{PM}_{10}$ mass concentration is estimated to originate from regional and far-range transport rather than local sources (Lenschow et al., 2001). In arid regions like Spain, wind-blown dust - partially imported from Africa may have a major impact (Escudero et al., 2007). Not only desert dust from the Sahara but also dust particles blown off agricultural soils could contribute to particle concentrations. A synthesis of measurements from multiple stations found that mineral aerosol is the main component in the $\mathrm{PM}_{10-2.5}$ aerosol fraction, but is only of minor importance in $\mathrm{PM}_{2.5}$ (Putaud et al., 2004). Agricultural dust is sometimes assumed to be responsible for the differences between measured and modelled $\mathrm{PM}_{10}$ concentrations in urban areas because considerable portions of urban $\mathrm{PM}_{10}$ may originate from far-range transport (Vautard et al., 2005).

Given the potential importance of soil dust aerosol for climate and air quality assessments and the possibility that dust emissions will change in future climates, improvements of our knowledge of dust sources and fluxes are essential.

This paper describes an exceptional dust event that greatly enhanced particle concentrations across Central Europe. The observations strongly suggest that most of this dust originated from a cultivated region within Europe. The body of observations provides a unique opportunity to characterise a case of anthropogenically induced soil dust emission and transport, which may ultimately help understanding of the changing role of soil dust aerosol under different climate conditions.

\section{Measurement data and meteorological calculations}

\subsection{Satellite images}

Due to the influence of dust particles on infrared (IR) radiation, airborne dust can be detected during day-time and night-time by brightness temperature difference (BTD) (Ackerman, 1997; Wald et al., 1998; Sokolik, 2002; Brindley and Russell, 2006; Merchant et al., 2006). Different absorption and emission properties of dust and the Earth's surface at different thermal wavelength bands causes the BTD to decrease in the presence of airborne dust. To detect airborne dust by remote sensing, we use a dust index based on brightness temperature (BT) and BTD, converted from thermal IR radiances measured by the SEVIRI (Spinning En- hanced Visible and InfraRed Imager) instrument on board the geostationary Meteosat Second Generation (MSG) satellite (Schmetz et al., 2002). The satellite is located at $3.5^{\circ} \mathrm{W}$ over the equator and has a horizontal resolution of $3 \mathrm{~km}$ at nadir and a time resolution of $15 \mathrm{~min}$. The dust index is composed of the BTD at 12.0-10.8 $\mu \mathrm{m}$ and at $10.8-8.7 \mu \mathrm{m}$, as well as of the BT at $10.8 \mu \mathrm{m}$ (Schepanski et al., 2007). It is based on the same BTs as EUMETSAT's dust index product of MSG scenes offered on its website (http://www.eumetsat.int).

In an alternative approach, mobilised dust can be identified in Moderate-resolution Imaging Spectroradiometer (MODIS) 721-composite pictures, using the near infrared $(2.155 \mu \mathrm{m})$ and two shortwave $(0.876 \mu \mathrm{m}, 0.670 \mu \mathrm{m})$ wavelength bands. The MODIS instrument flies on board of two polar-orbiting satellites, Terra and Aqua. True colour and composite pictures are available on the MODIS web site (http://rapidfire.sci.gsfc.nasa.gov/subsets, as of 11 June 2007) at $1 \mathrm{~km}, 500 \mathrm{~m}$ and $250 \mathrm{~m}$ horizontal resolution for predefined subsets. Here we use part of the Europe_2_04 Subset with a horizontal resolution of $250 \mathrm{~m}$, imaged by the Earth Observing System (EOS) Aqua satellite on March 23 at 10:50 UTC. Due to its high reflectivity in the near infrared wavelength band $(2-155 \mu \mathrm{m})$ and its absorbent behaviour in the 0.670 and $0.876 \mu \mathrm{m}$ wavelength bands, vegetation appears green in the composite picture. Bare soil causes a high reflectivity in all wavelength bands, especially in the $2.155 \mu \mathrm{m}$ wavelength band, so they can be identified by a brownish colour.

\subsection{Lidar and Sun photometer observations}

A low-cost, small and compact, semi-automated Raman lidar routinely monitors the troposphere over Leipzig (Althausen et al., 2004). For day-time periods, the vertical profile of the particle extinction coefficient is determined at $0.532 \mu \mathrm{m}$ wavelength from the elastically backscattered aerosol signal. The extinction profile can be retrieved in a well-mixed boundary layer if a Sun photometer measurement of the total aerosol optical depth is available (Ansmann and Müller, 2005), as is the case here. Due to the incomplete overlap of the laser beam with the receiver field of view, the retrieval of the profile is generally restricted to heights above about $400 \mathrm{~m}$.

Leipzig is also an Aerosol Robotic Network (AERONET) site (Holben et al., 1998). The Leipzig Sun photometer measures the aerosol optical depth (AOD) at the 8 wavelengths $0.340,0.380,0.440,0.500,0.675,0.870,1.02$, and $1.64 \mu \mathrm{m}$. Measurements are made during day-time in 15 min intervals, as long as the Sun is not obscured by clouds. The Leipzig Sun photometer has been calibrated at least every two years with its latest calibration dating from autumn 2006. The measurement uncertainty of AOD is 0.02 at $0.340 \mu \mathrm{m}$ and 0.005-0.01 at greater wavelengths. AERONET data can be accessed through its corresponding website (http://aeronet. gsfc.nasa.gov). 
Table 1. Government institutions who supplied $\mathrm{PM}_{10}$ network data to this study. The two last columns indicate the total number of $\mathrm{PM}_{10}$ observation sites as well as the number of sites where the dust plume could actually be detected.

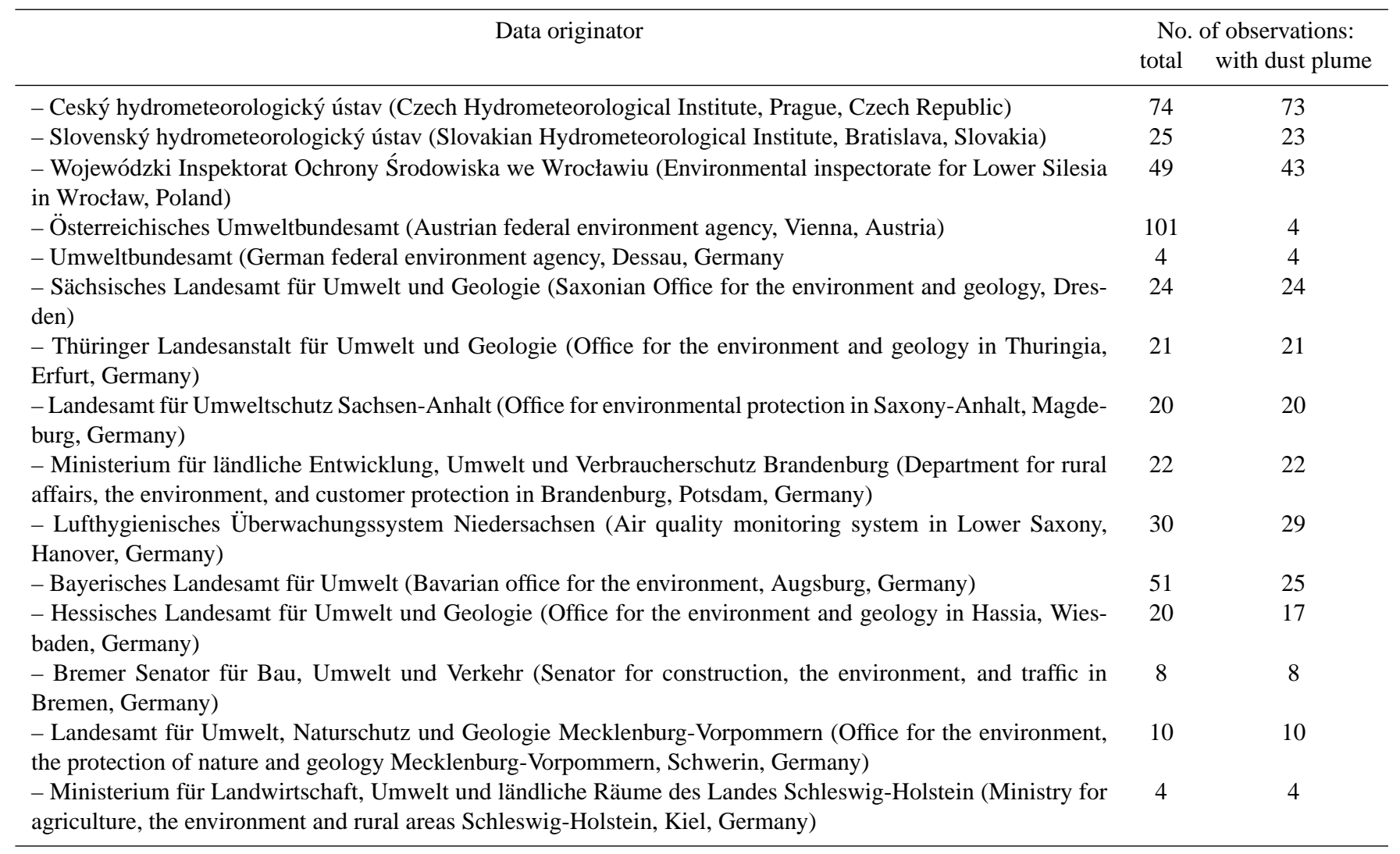

Table 2. In situ measurements used to characterise the dust plume: Parameters, methods and instruments.

\begin{tabular}{|c|c|c|c|}
\hline Aerosol parameter & Method & Instrument & Reference \\
\hline $\begin{array}{l}\text { Particle number size distribu- } \\
\text { tion }(0.8-8 \mu \mathrm{m})\end{array}$ & Time-of flight size classification & $\begin{array}{l}\text { Aerodynamic Particle Sizer } \\
\text { (APS), TSI model } 3321\end{array}$ & Peters and Leith (2003) \\
\hline $\begin{array}{l}\text { Mass concentrations of } \mathrm{PM}_{10} \text {, } \\
\mathrm{PM}_{2.5} \text { and } \mathrm{PM}_{1}\end{array}$ & Light scattering size classification & $\begin{array}{l}\text { Environmental Dust Monitor } \\
\text { (EDM), Grimm model } 107\end{array}$ & Grover et al. (2006) \\
\hline $\begin{array}{l}\text { Mass concentrations of } \mathrm{PM}_{10} \\
\text { and } \mathrm{PM}_{2.5}\end{array}$ & $\begin{array}{l}\text { Gravimetry of quartz fiber filter sam- } \\
\text { ples at } 50 \% \text { relative humidity }\end{array}$ & DHA-80 air sampler & Plewka et al. (2004) \\
\hline Ion concentrations & Ion chromatography & $\begin{array}{l}\text { Ion chromatograph } 690, \\
\text { Methohm, Switzerland }\end{array}$ & $\begin{array}{l}\text { Brüggemann and Rolle } \\
\text { (1998) }\end{array}$ \\
\hline Metal concentrations & $\begin{array}{l}\text { Inductively coupled plasma optical } \\
\text { emission spectrometry (ICP-OES) }\end{array}$ & & DIN (1998) \\
\hline
\end{tabular}




\section{$2.3 \quad \mathrm{PM}_{10}$ network observations}

$\mathrm{PM}_{10}$ mass concentrations are monitored on a routine basis in every member state of the European Union. For this paper we evaluated time series from more than 360 governmental air pollution monitoring stations in Slovakia, the Czech Republic, Austria, Poland, and Germany. Most data were available at a time resolution of $30 \mathrm{~min}$ and measured by either the Tempered Oscillating Microbalance (TEOM) (Allen et al., 1997), or beta-gauge attenuation (Macias and Husar, 1976). Table 1 lists the government institutions that supplied data as well as the number of sites in each network.

\subsection{In situ measurements in Saxony}

In-situ measurements of atmospheric aerosols were conducted during the dust episode at a number of measurement sites in Saxony, Germany. The most comprehensive set of measurements was carried out at the atmospheric research station Melpitz $\left(51.2^{\circ} \mathrm{N}, 12.9^{\circ} \mathrm{E}\right)$, where atmospheric aerosols have been extensively characterised since 1996 (Birmili et al., 2001; Neusüss et al., 2002; Spindler et al., 2004; Engler et al., 2007). The suite of measurements and chemical particle analyses is summarised in Table 2.

Particle size distributions from the twin differential mobility particle sizer (TDMPS) and the aerodynamic particle sizer (APS) were combined to obtain a complete particle spectrum between 0.003 and $8 \mu \mathrm{m}$. Details of the evaluation can be found in the Appendix. Particle mass concentrations of $\mathrm{PM}_{10}, \mathrm{PM}_{2.5}$ and $\mathrm{PM}_{1}$ were determined using a Grimm Environmental Dust Monitor (EDM, model 107, Grimm GmbH, Ainring, Germany). As the response of the EDM is a function of the particle refractive index, we are aware of possible deviations from the true gravimetric mass in the case of strongly absorbing aerosols. The EDM was equipped with a heated inlet that allows to remove highly volatile particle material at $50^{\circ} \mathrm{C}$.

Particle number size distributions up to $0.8 \mu \mathrm{m}$ were also recorded at two other sites in Saxony, Niesky $\left(51.3^{\circ} \mathrm{N}\right.$, $\left.14.8^{\circ} \mathrm{E}\right)$ and Schwartenberg $\left(50.7^{\circ} \mathrm{N}, 13.5^{\circ} \mathrm{E}\right)$ using differential mobility particle sizers. Table 2 also lists the methods of chemical analysis that were performed for samples collected at Melpitz, Niesky, Schwartenberg, as well as Dresden-Nord and Dresden-Herzogingarten (both $51.0^{\circ} \mathrm{N}$, $\left.13.7^{\circ} \mathrm{E}\right)$. Here, aerosol particles were collected using $\mathrm{PM}_{10}$ and $\mathrm{PM}_{2.5}$ high volume filter samplers over $24 \mathrm{~h}$ on $150 \mathrm{~mm}$ quartz fibre filters (MK 360, Munktell Filter AG, Falun, Sweden). After equilibration at $50 \%$ relative humidity the filters were weighed and divided for the different subsequent analyses as described in Plewka et al. (2004).



Fig. 1. Dust source activation on 23 March 11:00 UTC over the southern Ukraine (arrow). The image shows MSG dust index images, based on BTD using the $8.7 \mu \mathrm{m}, 10.8 \mu \mathrm{m}$ and $12.0 \mu \mathrm{m}$ wavelength bands of the SEVIRI instrument.

\section{The Ukrainian dust plume}

\subsection{Satellite images}

Due to its high spatio-temporal resolution the SEVIRI instrument is an accurate tool to track dust source activation and transport. Figure 1 shows SEVIRI's MSG dust index image on 23 March 2007, 11:00 UTC and reveals a strong event of dust emission over the Southern Ukraine, indicated by magenta colour. Due to continuing high wind speeds, even a second event of dust source activation (not shown) could be detected on the following day. As will be shown below, the area of dust emission was located exactly on a pathway that leads the air mass to Central Europe.

The source region can be seen at higher resolution in the MODIS Aqua composite picture in Fig. 2. This image displays shows the southern and eastern area of the Kahkova Reservoir and illustrates dust emission occurring over an area of approximately $20000 \mathrm{~km}^{2}$. Brown stripes of dust can be seen over the blue-black colour of the reservoir, indicating dust mobilised from agricultural soil. In fact, the composite picture is not very sensitive for airborne dust but the colour of the dust plume can be seen to agree with that of the surface, which is mostly agricultural soil. Southern Ukraine is known for its fertile black earth (Chernozem), which has been intensively used for agriculture in the past and can, to date, be classified as erodible soil. 


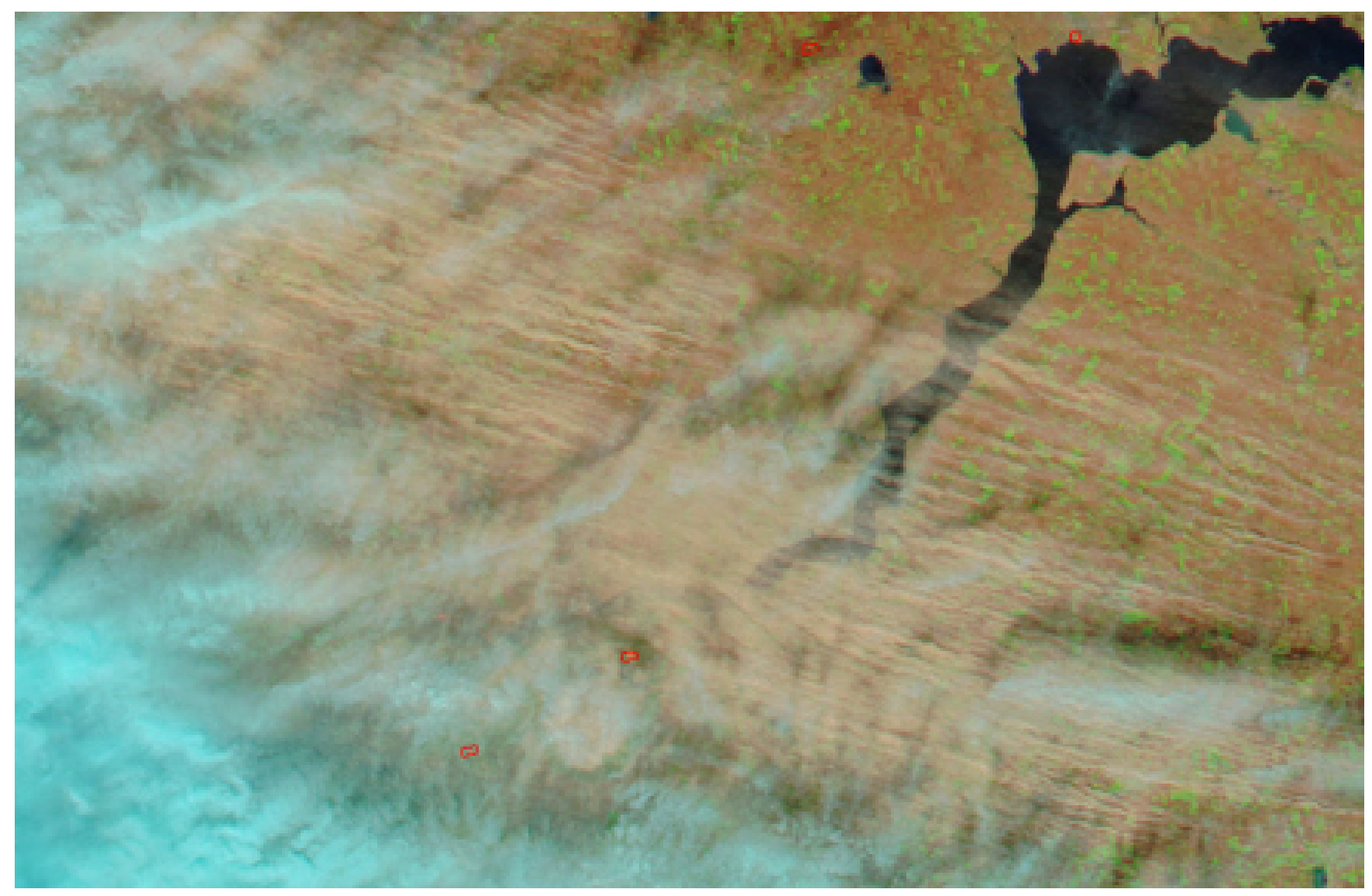

Fig. 2. The MODIS-Aqua composite image of Southern Ukraine on 23 March 2007, 10:50 UTC reveals the large scale emission of agricultural dust. The reservoir lake of Kakhovskaya on the Dnieper River can be seen in dark blue, ice clouds in light blue. Red boxes indicates thermal anomalies, caused in most cases by fire or even flares from a gas well. The dimensions of the area shown is $210 \times 146 \mathrm{~km}$.

On 23 March, meteorological observations in the southern and eastern area around the Kahkova Reservoir report average wind speeds up to $15 \mathrm{~m} \mathrm{~s}^{-1}$ and wind gusts up to $25 \mathrm{~m} \mathrm{~s}^{-1}$ and confirm "observations of atmospheric dust". It is likely that these unusually high surface wind speeds in combination with a preceding drought period of two weeks as well as the lack of vegetation in March led to the high dust emission rates. Interestingly, the dust emission and transport can be seen to take place along lengthy filaments, located between 1.5 and $3 \mathrm{~km}$ apart (Fig. 2). A speculative explanation for these filaments is that the sources are small areas, i.e. individual fields are emitting dust particles, while others do not - depending on orientation, crop growth, or similar factors. In this case the filaments observed in the satellite retrievals would be just plumes from localized emissions, which do not rapidly mix because of the high wind speeds.

\subsection{Synoptic situation}

On 23 and 24 March 2007 the synoptic situation over Europe was governed by a high-low dipole pattern due to a low pressure area over the Mediterranean Sea and a high pres- sure region built up by a permanent anticyclone located over Fennoscandinavia and an anticyclone located over South Russia (Fig. 3). The eastward moving Mediterranean depression on the one side and the persistent high pressure area on the other side forced an increasing pressure gradient over the Black Sea and Southern Ukraine, generating a low-level jet into Central Europe. High surface wind speeds prevailed over the southern Ukraine on 23 March, continuing until 25 March. The low-level jet effected the transport of a dry and subsiding air from the Black Sea area to Central Europe along a narrow corridor: Starting on 23 March over the Ukraine, the air mass was transported across Slovakia, Poland, the Czech Republic, and reaches Germany on 24 March. The transect was characterised by high wind speeds of more than $15 \mathrm{~m} \mathrm{~s}^{-1}$ and low relative humidities.

\subsection{Back trajectories}

The exact pathway of the air mass arriving in Central Europe was verified through 3-D backward trajectory computations. For the second half of March 2007 backward trajectories were calculated by fine mesh analysis (Reimer and Scherer, 

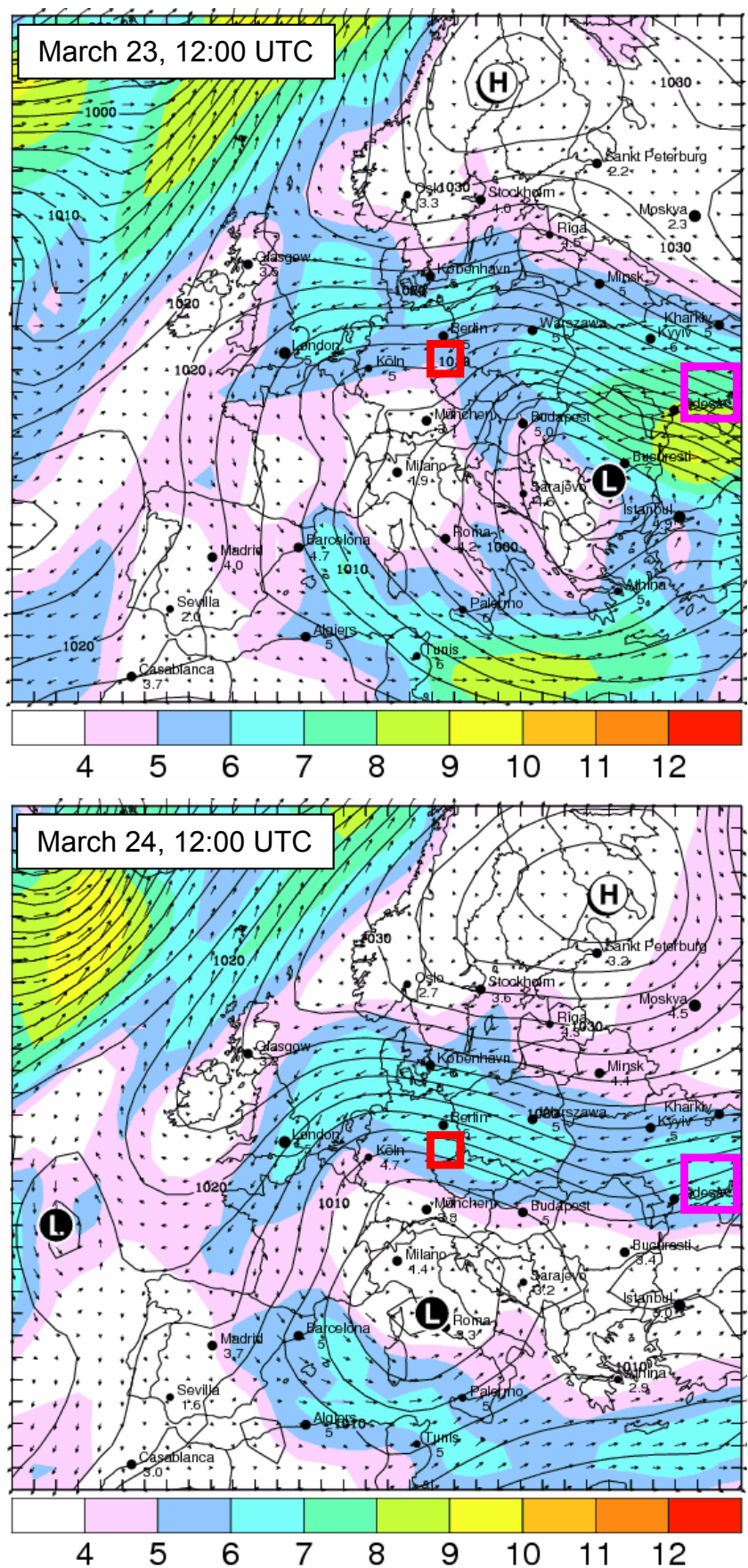

Fig. 3. Charts of sealevel pressure $(\mathrm{hPa})$ and horizontal surface wind speeds in Beaufort (colour code) on 23 and 24 March 2007, 12:00 UTC respectively. The charts were produced using the MM5 model and selected from the EURAD products offered by the University of Cologne, Germany (http://www.eurad.uni-koeln.de). Squares indicate the source region of the dust plume (magenta) and the region of the key measurements in Saxony, Germany (red).

1992), starting at 20 receptor locations in Germany at a 10-min frequency. For each site three types of trajectories

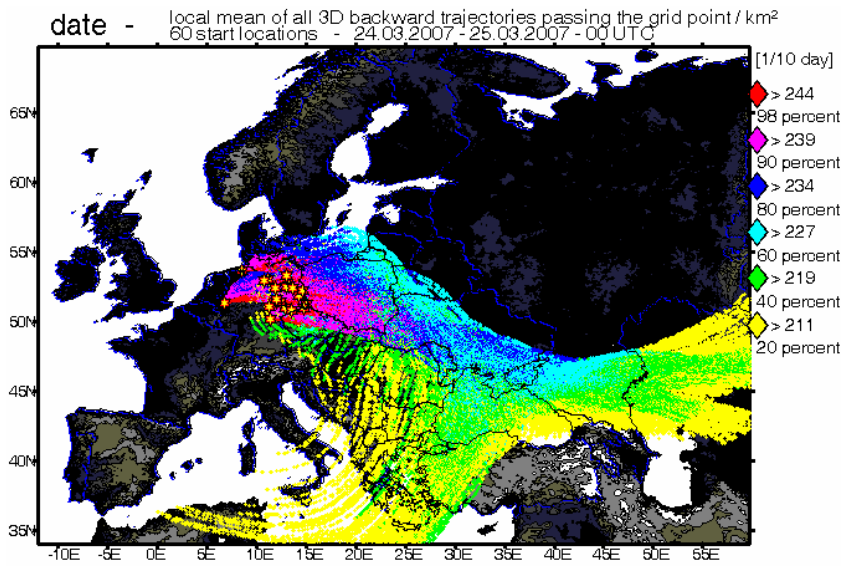

(a)

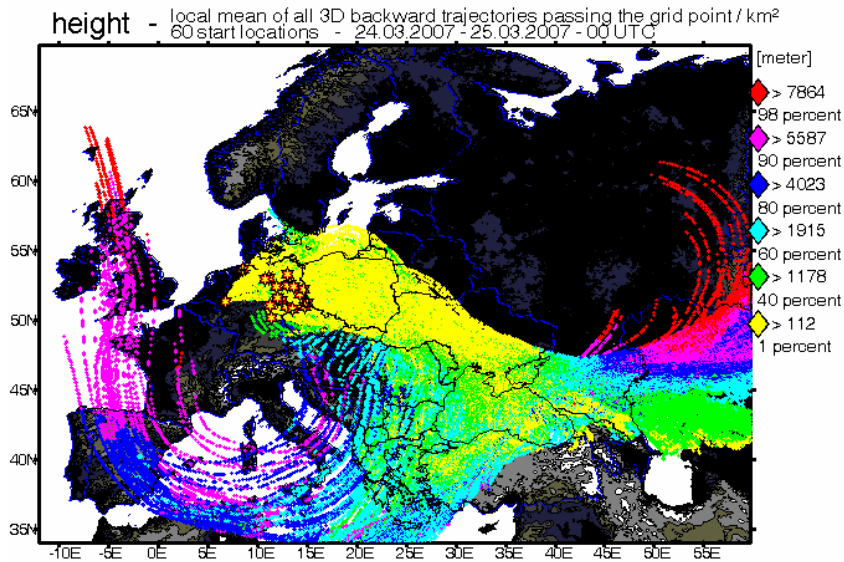

(b)

Fig. 4. Superposition of back trajectories originating on 24 March 2007 at 20 receptor sites in Germany. Colour coding indicates (a) date and (b) height above the ground.

were calculated: One driven by the 3-D wind field only, and two more with constant sedimentation velocities of 0.5 and $1.0 \mathrm{~mm} \mathrm{~s}^{-1}$. The two sedimentation velocities were intended to simulate gravitational settling of coarse particles and correspond to dust particle diameters of 2.8 and $4.0 \mu \mathrm{m}$, respectively. The bundles of back trajectories arriving in Germany are shown in Fig. 4. In close analogy to Fig. 3 the trajectory model predicts a strongly channelled flow from the region of the Caspian Sea over Ukraine towards Central Europe. Air from the northern shore of the Black Sea is predicted to reach Germany within only 18 to $24 \mathrm{~h}$ (Fig. 4a). The boundary layer jet can best seen in yellow colour in Fig. 4b, illustrating that between the Ukraine and Germany the trajectories moved within the boundary layer mostly at heights below $1.2 \mathrm{~km}$. 




Fig. 5. Time series of $\mathrm{PM}_{10}$ mass concentrations at a number of selected air quality monitoring stations in Slovakia, the Czech Republic, Poland, and Germany. The data show the singular and shortlived nature of the dust plume as measured across the networks of stations.

\section{Aerosol measurements in Central Europe}

\section{1 $\mathrm{PM}_{10}$ network observations}

\subsubsection{Time series of $\mathrm{PM}_{10}$}

Exceptionally high concentrations of airborne particles were observed on 24 March 2007 at numerous air pollution monitoring stations in Slovakia, the Czech republic, Poland, Austria and Germany. Figure 5 illustrates the time series of $\mathrm{PM}_{10}$ at a number of selected monitoring stations: The dust plume can be detected in the time histories of all monitoring stations as a clear, outstanding peak. Before the arrival of the dust plume, the concentrations were below $50 \mu \mathrm{g} \mathrm{m}^{-3}$ at most stations. The first station to detect the dust event in the late evening of 23 March was Košice in Eastern Slovakia (48. $7^{\circ}$ $\mathrm{N}, 21.2^{\circ} \mathrm{E}$ ), where $\mathrm{PM}_{10}$ concentrations increased dramatically within a matter of two hours (Fig. 5). During the entire day of 24 March, the plume was transported in westerly direction, traversing Central Europe within a confined band. $\mathrm{PM}_{10}$ concentrations rose to $1400 \mu \mathrm{g} \mathrm{m}^{-3}$ in Slovakia in the morning of $24 \mathrm{March}$, and up to $640 \mu \mathrm{g} \mathrm{m}^{-3}$ in Germany during mid-day.

\subsubsection{Geographic mapping of the dust event}

Figure 6 shows the map of peak $\mathrm{PM}_{10}$ mass concentrations during the dust event, generated from observational data at a total number of about 360 monitoring stations (cf. Table 1). The $\mathrm{PM}_{10}$ time series at all monitoring stations traversed by the dust cloud showed a pronounced maximum, and were similar in shape to those shown in Fig. 5. In order to simplify the amount of data, all individual time series were parametrised by Gaussian model curves, thereby yielding the peak value of $\mathrm{PM}_{10}$ concentration as well as the time of its occurrence.

The advancement of the dust cloud across Central Europe is visualised in Fig. 6. Shown are the frontal lines that indicate the temporal evolution of the dust cloud as well as the peak $\mathrm{PM}_{10}$ concentrations occurring along the pathway. Remarkably, the highest $\mathrm{PM}_{10}$ concentrations occurred in Slovakia and the Małopolskie voivodeship ${ }^{1}$ in Poland, which are the areas the closest to the source region in Ukraine. The other most affected areas include the Czech Republic and Saxony in Germany. It can be seen that the dust cloud moved faster across the south of Poland than across the Czech Republic. Two reasons are responsible for this, the flatter terrain in Poland and the decrease of the wind speed towards the south, where the centre of the low pressure system resides.

After passing over Germany, the dust cloud reached the North Sea in the afternoon of 24 March. Traces of the dust plume could still be detected over South England, as indicated by UK Automatic Particulate Monitoring Network data (not shown). A time lag analysis of the multiple station data suggests that the air mass was moving at relatively constant speeds around $20 \mathrm{~m} \mathrm{~s}^{-1}$ across Central Europe.

Towards its southern edge, the dust plume could be delimited accurately because of a relatively dense coverage of Austria and Germany with $\mathrm{PM}_{10}$ data. Meteorological observations reported a band of rainfall (daily sum: $5-8 \mathrm{~mm}$ ) to the southern edge of the dust cloud, which is the main reason why dust particles did not penetrate further south. The eastern and northern edge of the dust cloud could not be defined with the same accuracy because of the unavailability of $\mathrm{PM}_{10}$ observations for the Ukraine and some voivodeships of Poland.

\subsubsection{Estimation of the total amount of dust}

The $\mathrm{PM}_{10}$ mass concentration data was used to full capacity when estimating the total mass of particles present in the dust plume. Such an estimate will be the most accurate when examining the measurements close to source; we accordingly analysed $\mathrm{PM}_{10}$ time series from sites in the vicinity of the 04:00 CET frontal line of Fig. 6. Close to this frontal line lie, from north to south, the monitoring stations Tarnów and Nowy Sacz in Poland, and Prešov, Krompachy, Košice, and Velká Ida in Slovakia.

The transversal dimension of the dust plume was derived from Fig. 6. To determine the longitudinal dimension of the dust cloud, the flow field of the plume was split into volume elements passing across each of the six sites mentioned above. The speed of the air mass was determined individually for each volume element using the time lag of $\mathrm{PM}_{10}$ observations along the longitudinal axis. From this, time series of $\mathrm{PM}_{10}$ as a function of longitude could

\footnotetext{
${ }^{1}$ Voivodeships are units of administration in Poland.
} 


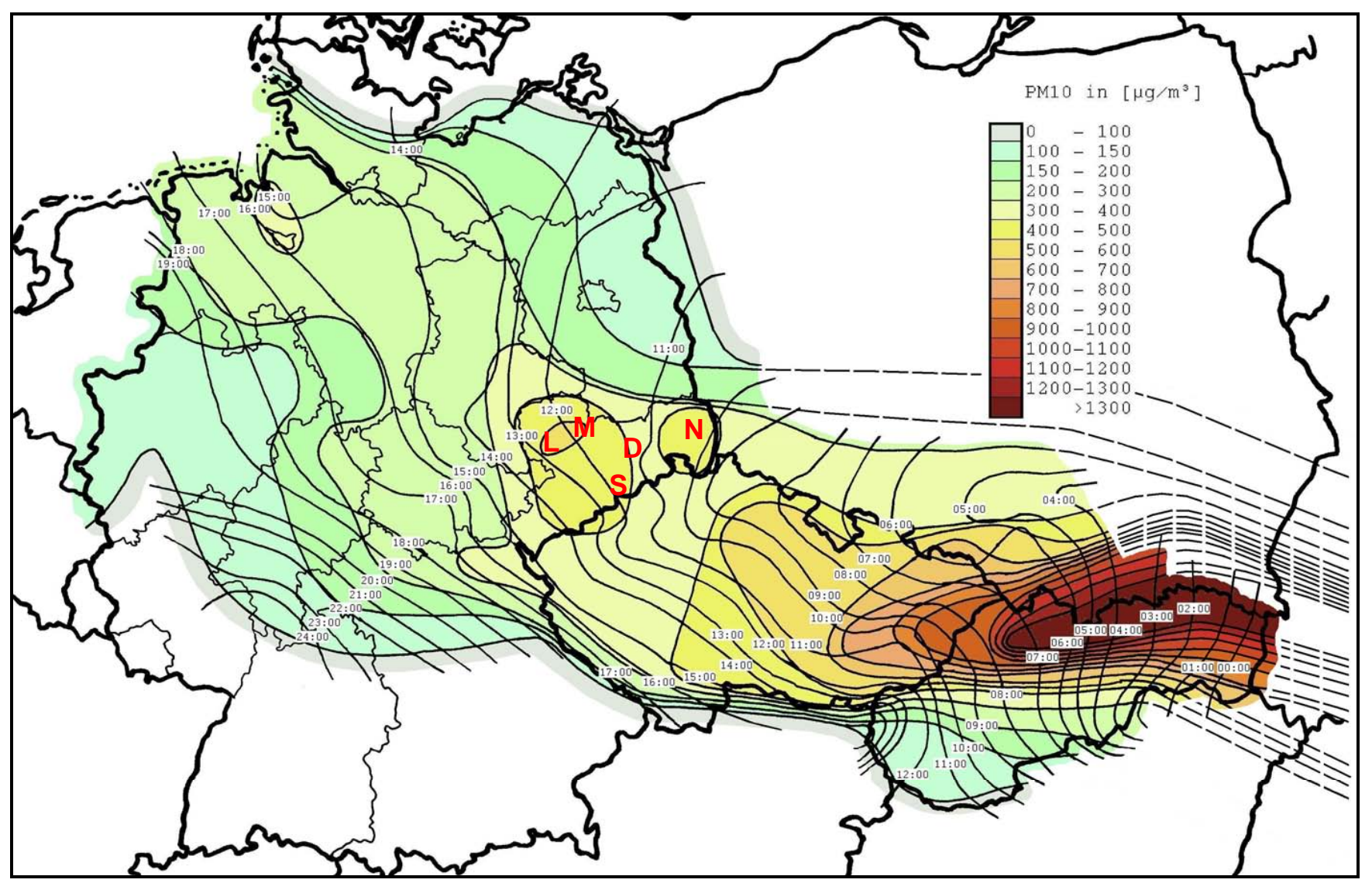

Fig. 6. Spatio-temporal evolution of the dust plume in Central Europe on 24 March 2007. The map is based on time series of PM 10 mass concentration at over 360 government monitoring stations in Slovakia, the Czech Republic, Austria, Poland, and Germany. Labelled frontal lines indicate where the peak values of $\mathrm{PM}_{10}$ occurred simultaneously. The peak $\mathrm{PM}_{10}$ concentration is coded in colour. The dust plume is delimited in grey if well supported by the observational data. Additional markers indicate the measurement sites Leipzig (L), Melpitz (M), Niesky (N), Schwartenberg (S) and Dresden (D). Dashed isolines are extrapolations along backtrajectories over areas of missing data.

be constructed. The vertical dimension of the of the dust cloud was estimated from radiosoundings (Source: University of Wyoming, http://weather.uwyo.edu/upperair/). The vertical profiles of the virtual potential temperature suggested a boundary layer height of $1.2 \mathrm{~km}$ (uncertainty range $1.0-1.4 \mathrm{~km})$ at Poprad-Ganovce in Slovakia, and $1.4 \mathrm{~km}$ (range 1.0-1.6 km) at Wrocław in Poland. These values were found to be in relatively good agreement with boundary layer heights determined further downwind at Prague in the Czech Republic and Lindenberg in Germany. An additional necessary assumption was that the particles were distributed homogeneously within the boundary layer, but this was supported by the lidar observations over Leipzig (Sect. 4.3). An integration over the entire concentration field yielded an approximation for the total dust mass in the atmosphere.

Our calculation yielded a total dust mass of $60 \mathrm{Gg}$ $( \pm 20 \mathrm{Gg})$ in the plume at 04:00 CET. Due to the upper size cut involved in $\mathrm{PM}_{10}$ sampling, this figure includes only particles smaller than $10 \mu \mathrm{m}$ aerodynamic diameter. The mass of the totally suspended dust may have accordingly been higher.

\subsection{Aerosol characteristics in Saxony}

Figure 7 compiles particle size distributions $(0.003-8 \mu \mathrm{m})$ as well as mass concentrations measured in Saxony before, during, and after the advection of the dust plume from Southern Ukraine. The particle volume size distribution in the top graph reveals the presence of a pronounced coarse particle mode, separated from the fine mode by a concentration minimum around $1 \mu \mathrm{m}$. Featuring an early concentration rise at 00:00 CET, the coarse mode attained its maximum concentration in Melpitz at around 11:00 CET, and across Saxony between 09:30 and 14:00 CET. Quite obviously, the coarse particle concentration changes independently from the fine particles. During its time of maximum concentration the coarse mode was characterised by a count median diameter around $2 \mu \mathrm{m}$ and a volume median diameter of about $3 \mu \mathrm{m}$. In the afternoon, the coarse mode concentration decreased to its former level.

The size-fractionated mass concentrations (Fig. 7, lower top graph) confirm that the mass concentration of $\mathrm{PM}_{10}$ is almost entirely dominated by the coarser fraction. $\mathrm{PM}_{1}$, 

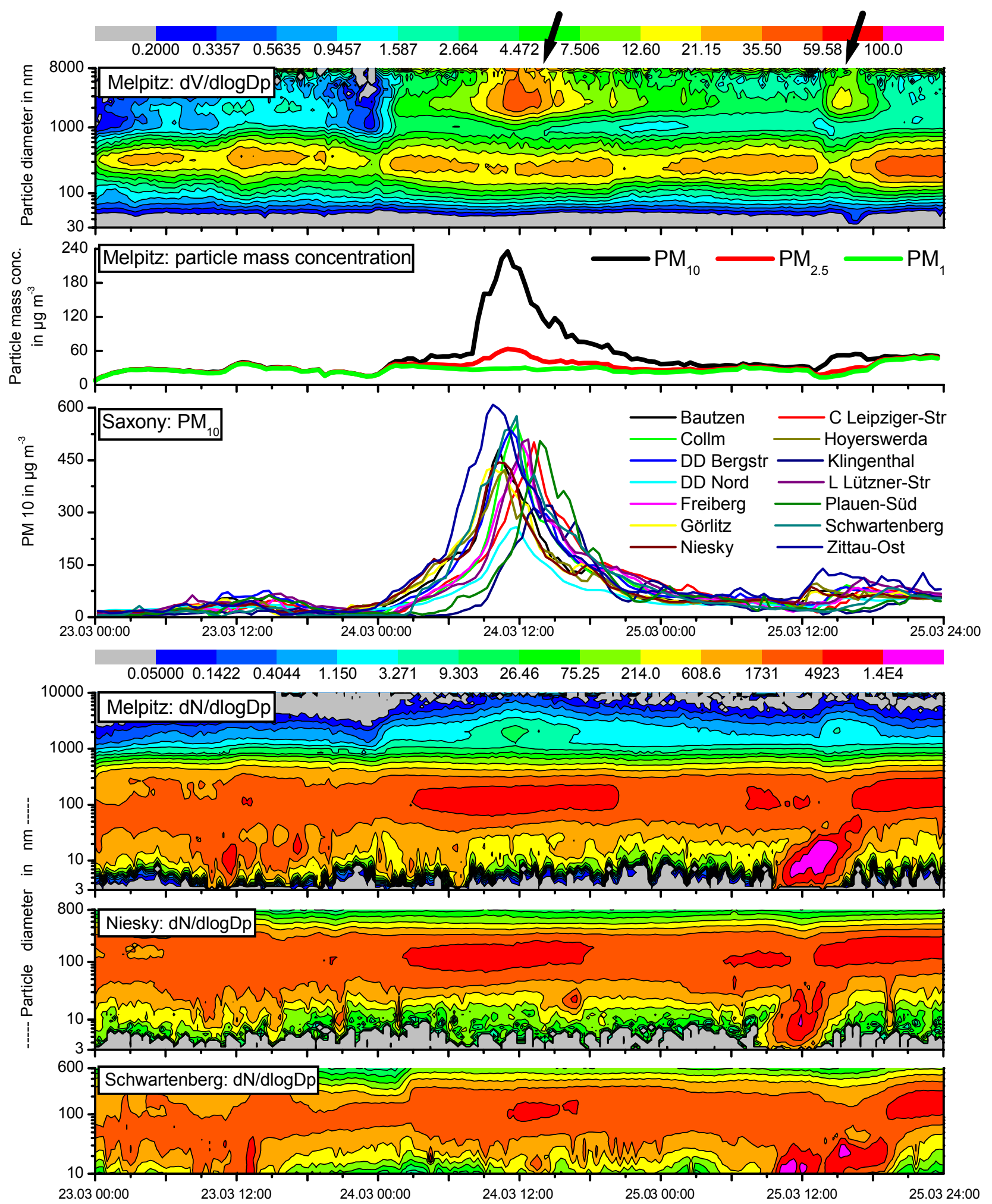

Fig. 7. In situ aerosol observations in Saxony, Germany, between 23 and 25 March 2007. High coarse particle concentrations are indicated by arrows. Top graph: Particle volume size distribution measured by TDMPS and APS at Melpitz. Lower top graph: Particle mass concentration measured by the Grimm EDM. Third graph: $\mathrm{PM}_{10}$ mass concentration at 14 monitoring stations measured by TEOM. Bottom graphs: Particle number size distributions measured at the rural background stations Melpitz, Niesky and Schwartenberg. Times are given in CET. 




Fig. 8. Vertical profile of the volume extinction coefficient of the aerosol as retrieved from Lidar observations at $0.532 \mu \mathrm{m}$ wavelength at Leipzig, on 24 March 2007, 12:33-13:44 UTC. The height of the dust layer was about $1800 \mathrm{~m}$. The free troposphere was almost deplete of aerosol and clouds during the observation period. Below $500 \mathrm{~m}$ the profile was extrapolated towards the ground.

which represents the fine mode, remains practically constant throughout March 24, and $\mathrm{PM}_{2.5}$ shows a diurnal variation by a factor of two. During the main dust event $\mathrm{PM}_{10}$ is made up to $75 \%$ by the coarse fraction $\mathrm{PM}_{10-2.5}$. Time series of $\mathrm{PM}_{10}$ mass concentrations in Fig. 7 (centre graph) indicates a similar spatial homogeneity of their peak concentrations across 14 measurement sites in Saxony.Simultaneous particle number size distribution measurements at three observation sites across Saxony (Fig. 7, bottom graph) demonstrate a homogeneously distributed accumulation mode (count mean diameters around $100 \mathrm{~nm}$ ) across a few hundred kilometres. The spatial homogeneity of the air mass could also be confirmed by meteorological and gas phase chemical parameters (not shown). The relative humidity was $40-50 \%$ around mid-day, emphasizing that the air inside the boundary layer jet was dry in comparison to the centre of the low pressure system. The low relative humidities imply that the optical observations in Sect. 4.3 refer to an overwhelmingly dry aerosol.

It is of a certain interest that one day later (25 March, 14:00 CET) a second, albeit less pronounced maximum of coarse particle concentration occurred. This second event was associated with high concentrations of particles $<40 \mathrm{~nm}$ as well as temporarily reduced concentrations of the accumulation mode. A decrease in the accumulation mode in the middle of the day can be indicative of vertical mixing with air from aloft. The observation therefore suggests that

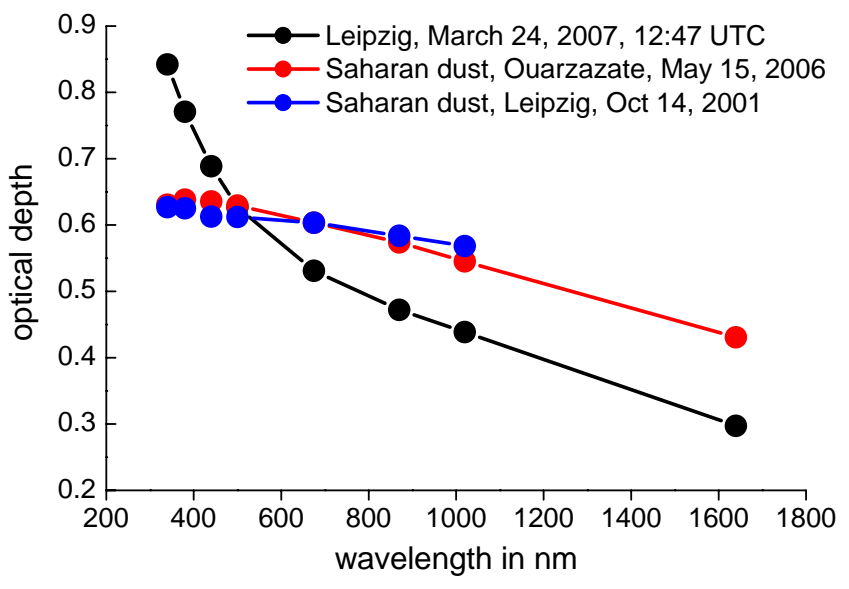

Fig. 9. Aerosol optical depth as a function of wavelength as retrieved from the Leipzig AERONET Sun photometer. The data from 24 March 2007 are complemented by two cases featuring Saharan dust aerosol: Ouarzazate, Southern Morocco, on 15 May 2006, 06:41-08:31 UTC, and Leipzig, 14 October 2001, 10:4211:42 UTC. All measurements were performed using the same Sun photometer.

the coarse mode particles could be mixed down from a remotely transported layer aloft. The formation of the new ultrafine particles $<40 \mathrm{~nm}$ at all sites could likewise be associated to this mixing process, as this process tends to bring about favourable conditions for the formation of new particles (Nilsson et al., 2001).

\subsection{Lidar and Sun photometer observations}

Figure 8 shows lidar observations that were recorded during the time of maximum dust concentration at Leipzig ("L" in Fig. 6). The vertical profile of the volume extinction coefficient suggests that the aerosol plume arriving on 24 March in Central Europe was confined to the lowest two kilometers of the troposphere. On 24 March, no lofted aerosol layers could be detected in the free troposphere, neither in the morning nor the early afternoon. Apparently, the aerosol layer originating from the northern shore of the Black Sea became well mixed during the long-range transport with strong winds. The lidar observations revealed a high aerosol optical depth (AOD) of 0.65 and high extinction coefficients of 300 to $400 \mathrm{M} \mathrm{m}^{-1}$ at $0.532 \mu \mathrm{m}$ throughout the dust layer in the early afternoon of 24 March 2007. The typical background values at Leipzig are substantially lower, around 0.1 and 80 $90 \mathrm{M} \mathrm{m}^{-1}$, respectively (Mattis et al., 2004).

At 13:02 UTC the AERONET Sun photometer measured an AOD of 0.71 at $0.500 \mu \mathrm{m}$ at the station Leipzig (see Fig. 9). An Ångström exponent, which is an indicator of relative particle size (Ångström, 1961), was derived by fitting all optical depths across the wavelength interval 0.440 $0.870 \mu \mathrm{m}$. The resulting Ångström exponent of 0.46 is in 




Fig. 10. Size fractionated PM mass concentrations measured in Meliptz between 23 and 25 March 2007 using an EDM. "volatile" denotes the mass fraction that is volatile at $50^{\circ} \mathrm{C}$.

the range of previous observations of desert dust layers $(0.2$, 0.5, 1.1 in Müller et al., 2007) but rather outside the range of biomass burning and continental pollution aerosols (10 observations between 1.0 and 1.4 in Müller et al., 2007). In addition, the extinction-to-backscatter ratio (lidar ratio) of $60 \mathrm{sr}$ retrieved from the combined AERONET (optical depth) and lidar observations (column-integrated backscatter coefficient) shows a clear signature of non-spherical soil or dust particles. In the case of a large fraction of large particles as measured at ground, the lidar ratio would be $20-25 \mathrm{sr}$ according to Mie scattering theory, which assumes spherical particles. As shown during our previous long-term measurements, the lidar ratio for obviously non-spherical particles can be larger by a factor of 2-3 compared to spherical particles (Mattis et al., 2002).

The Sun photometer measurements from 24 March 2007 are complemented in Fig. 9 by two cases featuring Sahara dust aerosol, one measured in immediate vicinity of the Sahara, at Ouarzazate, Southern Marocco, on 15 May 2006, and another after a major transport event of a Saharan dust layer to Leipzig on 14 October 2001 (Müller et al., 2003; Ansmann et al., 2003). The comparison of the Saharan dust and the Ukrainian soil dust spectra reveal that the aerosol on 24 March was composed of fine mode particles (continental haze), indicated by a strong spectral dependence of the optical depth from $0.340-0.600 \mu \mathrm{m}$, and coarse mode particles which cause a similarly flat spectral slope of the optical depth in the range from $0.80-1.70 \mu \mathrm{m}$ as the Saharan dust particles. The contribution of anthropogenic fine mode particles to the total particle-related optical depth is estimated

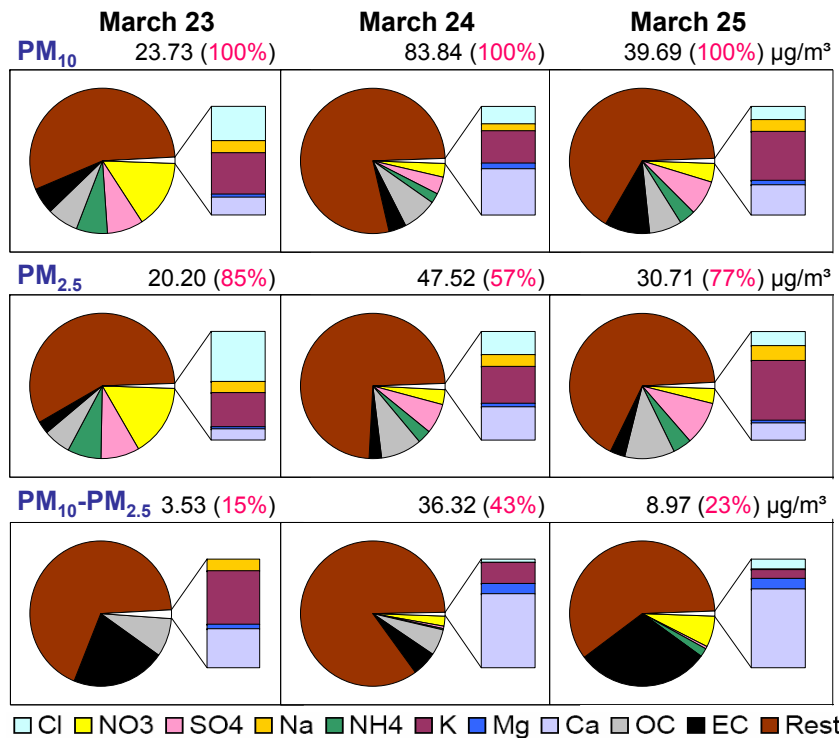

Fig. 11. Main components of bulk PM on 23 March (clean air mass), 24 March (dust event), and 25 March 2007 (continental air mass) at Melpitz. The circular charts indicate relative mass fractions. Total mass concentrations in $\mu \mathrm{g} \mathrm{m}^{-3}$ and mass fractions relative to $\mathrm{PM}_{10}$ are added in black and red font, respectively.

to be about 0.1 . Thus, $80 \%$ of the optical depth results from light extinction by the soil dust.

\subsection{Physico-chemical and chemical properties}

\subsubsection{Volatility of bulk $\mathrm{PM}$ at $50^{\circ} \mathrm{C}$}

Figure 10 shows time series of PM concentrations measured by the EDM instrument. The mean mass concentrations for $\mathrm{PM}_{10}$ and $\mathrm{PM}_{2.5}$ over the three days were 50.7 and $32.0 \mu \mathrm{g} \mathrm{m}^{-3}$, and in fair agreement with corresponding gravimetric measurements of 49.1 and $32.8 \mu \mathrm{g} \mathrm{m}^{-3}$, respectively. $\mathrm{PM}_{1}$, representing the fine particle mode, was found to consist between 11 and $67 \%$ of material that was volatile at $50^{\circ} \mathrm{C}$. (The main volatile specie evaporating at $50^{\circ} \mathrm{C}$ is particulate nitrate (Hildemann et al., 1984).) In contrast, the coarse particle fractions, $\mathrm{PM}_{2.5-1}$ and $\mathrm{PM}_{10-2.5}$ contained practically no material that volatilises at $50^{\circ} \mathrm{C}$. The results from the EDM add up to the impression that increase in total particulate mass on March 24 was caused by involatile material concentrated mainly in the $\mathrm{PM}_{10-2.5}$ fraction.

\subsubsection{Main components of bulk PM}

Figure 11 gives an overview of the mass concentrations of selected compounds for daily samples of $\mathrm{PM}_{10}$ and $\mathrm{PM}_{2.5}$ at Melpitz on 23, 24 and 25 March. Here, concentrations for $\mathrm{PM}_{10-2.5}$ were calculated by subtracting the value of $\mathrm{PM}_{2.5}$ from that of $\mathrm{PM}_{10}$. As shown before, $\mathrm{PM}_{10}$ and $\mathrm{PM}_{10-2.5}$ were significantly increased on 23 March by the impact of 
the dust plume, and $\mathrm{PM}_{10}$ reached a daily average value of $84 \mu \mathrm{g} \mathrm{m}^{-3}$ on 24 March. Again, the major mass gain from 23 March to 24 March is caused by the coarse fraction $\mathrm{PM}_{10-2.5}$, which increased by a factor of 10 .

The chemical speciation identified major amounts of soluble ions (ca. 30\%) in $\mathrm{PM}_{2.5}$ on 23 March and a total carbon (TC) fraction of about $8 \%$. $\mathrm{PM}_{10-2.5}$, in contrast, features only negligible amounts of soluble ions, about $30 \%$ carbonaceous material, and an overwhelming fraction $(\sim 70 \%)$ of unidentified material. The unidentified material contains those compounds that are neither soluble, ionic, nor carbonaceous. The major class representing this unidentified fraction in atmospheric aerosols is crustal material, which typically includes silicates and insoluble carbonates (e.g. FernandezEspinosa et al., 2002).

The air mass change from 23 March to 24 March featured, above all, an increase in the unidentified chemical fraction. This change is most notably in $\mathrm{PM}_{10-2.5}$, where the unidentified fraction attains a share of $\sim 85 \%$. This is a strong indicator for the presence of crustal material in the dust plume. On 25 March, the bulk PM composition changes again, now with a reduced share of unidentified material but an increased fraction of carbonaceous material, notably elemental carbon (Fig. 11). To our experience such relative amounts of carbon are usual for continentally aged aerosols, so that this observation is not surprising based on air mass residence times of more than 6 days over land, as shown by trajectory calculations.

It is worth to note that the chemical analysis of PM samples from four additional sites (Dresden-Nord, DresdenHerzogingarten, Schwartenberg, Niesky) confirmed a similar degree of spatial homogeneity of the dust plume as found earlier in Sect. 4.2, now with respect to chemical particle composition.

\subsubsection{Ti and $\mathrm{Fe}$ in in bulk $\mathrm{PM}_{10}$}

Iron $(\mathrm{Fe})$ and Titanium (Ti) concentrations in daily $\mathrm{PM}_{10}$ samples are depicted as a function of time in Fig. 12. Like $\mathrm{PM}_{10}$ mass concentrations, extremely high concentrations up to $0.36 \mu \mathrm{g} \mathrm{m}^{-3}$ (Ti) and $4.4 \mu \mathrm{g} \mathrm{m}^{-3}$ (Fe) were observed at all measurement sites in Saxony on March 24, the day of the dust event. On the day of the dust event, the mass fractions of $\mathrm{Ti}$ and $\mathrm{Fe}$ were $0.24 \%$ and $3.2 \%$, respectively, at the rural stations Schwartenberg, Niesky, and Melpitz. On 28 March, in contrast, the corresponding values were merely 0.08 and $1.1 \%$. It is straightforward to see that the dust event correlates with an increased fraction of $\mathrm{Ti}$ and $\mathrm{Fe}$. To assess the geogenic contribution to each sample, the relative mass fractions of $\mathrm{Ti}$ and $\mathrm{Fe}$ were compared to their relative abundance in the upper continental crust. Taylor and McLennan (1985) report crustal abundances of $0.30 \%$ (Ti) and $3.50 \%(\mathrm{Fe})$, which are rather similar to the values observed on 24 March 2007. Ti originates almost solely from geogenic sources, and a simple mass balance model assuming geogenic dust to be



Fig. 12. Daily average mass concentrations of iron (Fe) and Titanium (Ti) in $\mathrm{PM}_{10}$ at the 5 sampling sites Dresden-Nord (DN), Dresden-Herzogingarten (DHG), Schwartenberg (SW), Niesky (N) and Melpitz (M) in Saxony, Germany between 3 and 28 March 2007. 24 March corresponds to the day of the dust event over central Europe.

the only source of Ti leads to the result that $80 \%$ of the $\mathrm{PM}_{10}$ mass concentration on 24 March would be geogenic dust. It is worth noting that this value agrees very well with the $80 \%$ mass fraction of unidentified material derived in Sect. 4.4.2.

\section{Discussion}

\subsection{Causes of the extreme PM concentrations}

The causes of the extreme values of $\mathrm{PM}_{10}$ on 24 March 2007 in Central Europe were severalfold. After a twoweek drought period in the southern Ukraine, high amounts of agricultural dust were activated under high surface wind speeds at a time of the year, when little vegetation was present. This dust was transported within only $18-24 \mathrm{~h}$ into Central Europe along a narrow boundary layer jet on the northern edge of a low pressure system. The rapid transport at low relative humidities (day-time values $40-50 \%$ ) prevented its efficient removal during the transect by dry or wet deposition. The fact that the dust plume could not expand into the free troposphere is considered to be the main 
reason for the high aerosol concentrations measured at the ground. In fact, no indications for lofting or mixing with clean free tropospheric air were found during the transport (Sect. 4.3). Radiosounding observations along the transport path of the plume yielded boundary layer heights between 1.0 and $1.6 \mathrm{~km}$, topped by a capping inversion (Sect. 4.1.3). A cause of the stability of the dust layer is the topping of the boundary layer with warm air merging from the south. In summary, the combination of the soil structure, strong local winds, and fast transport within a relatively dry and stable boundary make this dust event for Central Europe extraordinary.

\subsection{Influence of Saharan dust?}

Dust transport from the Ukraine into Central Europe is an unusual feature, and has not been documented in the literature. Rather than Southern Eurasia, the Sahara desert has traditionally been viewed as the main source region of remotely transported mineral dust in Europe. Saharan dust can usually be observed over Central Europe several times a year, but generally enters Europe via lofted aerosol layers (Ansmann et al., 2003; Barkan et al., 2005; Amiridis et al., 2005). While such detached layers may remain relatively stable, they need to mix with boundary layer air for the dust particles to reach the ground. Consequently, Saharan dust plumes spread and dilute over large areas and appear at the ground only at moderate concentrations. A record of $\mathrm{PM}_{10}$ observations at Hohenpeissenberg, Southern Germany, where Saharan dust is usually seen several times a year yielded $280 \mu \mathrm{g} \mathrm{m}^{-3}$ as a 7-year hourly maximum concentration (Christian Plass-Dülmer, personal communication). This is considerably lower than the maximum concentrations observed in the Ukrainian dust plume $\left(640 \mu \mathrm{g} \mathrm{m}^{-3}\right.$ at the station Borna, Germany) and illustrates the limited impact of Saharan dust intrusions on ground-based concentrations. From the features discussed in Sect. 5.1 it is very clear that the Ukrainian dust plume does not fall into the same meteorological transport category as the Saharan dust plume.

A second argument to rule out the influence of Saharan dust uses actual observations along transport path. According to Fig. 4, any dust from the Sahara would have been required to pass over the Aegean Sea, or Turkey and the Black Sea in order to reach the jet flow into Central Europe. Numerous cloudless SEVIRI satellite scans recorded on 23 March 2007 over these areas were scrutinized but did in fact not reveal any amounts of dust remotely comparable to those released over the Ukrainian source region. Any coarse dust present in the marine boundary layer would have likely been removed by the precipitation reported at many sites on the northern shore of the Mediterranean $(5-16 \mathrm{~mm}$ daily sums on 23 March).

The last doubts about the origin of the Ukrainian dust plume could be resolved by a geochemical analysis of dust particles collected in the Czech Republic (Hladil et al.,
$2008^{2}$ ) These authors compared the multi-elemental metal content, $\mathrm{Pb}$ isotope ratios, and the prevalence of biota (palynological analysis) of particles from the plume with soil dust samples collected in the Southern Ukraine. Their unequivocal conclusion is that the particles from the dust plume originated in the Southern Ukraine rather than in Africa.

\subsection{Influence of biomass burning?}

The MODIS composite image (Fig. 2) reveals small spots of fires in southern Ukraine at the time the dust was activated. However, the aerosol characteristics in the Ukrainian dust plume do not indicate strong contributions from biomass burning. Figure 11 demonstrated that only $10 \%$ of the $\mathrm{PM}_{10}$ mass concentration was carbonaceous on 24 March, which is low, for instance, compared to $80 \%$ in sub- $\mu \mathrm{m}$ PM reported in African biomass burning plumes (Formenti et al., 2003). Also, the Ångström exponent and the lidar ratio of the Ukrainian dust plume are far more typical for mineral dust than for biomass burning plumes (cf. Sect. 4.3). Observations of $\mathrm{CO}_{2}$ and $\mathrm{CO}$ by the German Federal Environment Agency on 24 March at Neuglobsow $\left(53.2^{\circ} \mathrm{N}, 13.0^{\circ} \mathrm{E}\right)$ yielded mixing ratios of $390 \mathrm{ppmV}$ and $240 \mathrm{ppbV}$, respectively. Both levels were representative of the continental European background and did not show any particular increase during the occurrence of the Ukrainian dust plume. For the reasons given we can safely exclude a major influence of biomass burning on the plume observed on 24 March 2007.

\subsection{Long-term representativeness}

To address the long-term representativeness of the Ukrainian dust plume observations, existing long-term time series of daily PM mass concentrations and chemical composition at Melpitz were screened for similar events. On 24 March, the coarse PM mass fraction $\left(\mathrm{PM}_{10-2.5} / \mathrm{PM}_{10}\right)$ attained a daily mean value of $43 \%$ (Fig. 11). $\mathrm{PM}_{2.5}$ has been available since May 2004, and the second-highest coarse PM mass fraction since then was $21 \%$ (23 July 2005). The latter event, however, occurred in westerly Atlantic air and was therefore characterized by local dust resuspension under summertime conditions rather than remote transport.

$\mathrm{PM}_{10}$ mass concentrations and chemical composition have been available at Melpitz since 1993. A screening of the data over the years 1993-2007 yielded that no single day showed the same chemical composition features as the aerosol in the dust plume of 24 March 2007. Two days with $\mathrm{PM}_{10}$ greater than $100 \mu \mathrm{g} \mathrm{m}^{-3}$ were found where where the ionic mass fractions were relatively low: 28 December $1996\left(\mathrm{PM}_{10}\right.$ $116 \mu \mathrm{g} \mathrm{m}^{-3}$, ionic mass fraction 27\%) and 11 December $2002\left(104 \mu \mathrm{g} \mathrm{m}^{-3}\right.$ and $27 \%$, respectively). A back trajectory

\footnotetext{
${ }^{2}$ Hladil, J., Strnad, L., Š́alek, M., et al.: An anomalous atmospheric dust deposition over Central Europe, 24 March 2007, and fingerprinting of the SE Ukrainian source, B. Geosci., submitted, 2008.
} 
analysis showed that both air masses originated in Central Russia, but were not particularly related to high wind speeds, so that their unidentified chemical fraction cannot be attributed to a specific area such as on 24 March 2007.

\subsection{Soil condition and desertification trends in Ukraine}

The total area of the Ukraine is $603700 \mathrm{~km}^{2}, 70 \%$ of which are used as farm lands. The southern Ukraine has been characterised as a "forest-steppe" zone, in its less droughty part, or as a "steppe" zone in its more droughty part. In both zones, human impact has almost completely removed the former native forests and steppe lands, and created large-scale agricultural units. In the wide "loess" plains the very fertile black earth (Chernozem) has formed, which belongs to the most fertile soils worldwide. Due to the intensive agricultural development, the soil has become prone to wind erosion and in fact, wind has been found to have eroded Ukrainian soils over an area of $220000 \mathrm{~km}^{2}$. Wind erosion in the area of the former USSR has been recognised in the scientific literature as early as the 1920s and in fact, a considerable body of scientific studies (exclusively in Russian language) have been directed towards identifying the reasons of wind erosion and their environmental and economic consequences (Dolgilevich, 1997; Larionov et al., 1997). Wind erosion has increased since the 1930s and particularly the 1950s when many natural areas were turned into intense agriculture. Currently, wind erosion in Eurasia gravitates to the southern forestless zone, where strong winds prevail. The areas of the most severe wind erosion are located in the European part and include the North Caucasus, Lower Don and, explicitely, the eastern and southern parts of Ukraine. A comparison of the climate of the past (ca. 100 years ago) with the climate of today shows that the territory of the Ukraine has become arid due to human activities. Consequently, wind erosion has become wide-spread even in areas formerly unaffected by wind erosion.

Meteorological statistics over the past 40 years indicated the frequency of dust storms was found to be 3-5 per year in the steppe zone, with an average duration of $8-17 \mathrm{~h}$ (Dolgilevich, 1997). Dust storms in the Ukraine are typically associated with wind speeds of $20 \mathrm{~m} \mathrm{~s}^{-1}$ and more with Chernozemic soils being the most susceptible to wind erosion. During dust storms, these soils can lose $70 \mathrm{t}$ of soil per ha and hour. Based on this statistics it can be recognised that the dust storm on March 23, 2007 was not very unusual for the southern Ukrainian region.

As early as the 1950s, counter-actions have been devised to diminish wind erosion. Until now about $10 \%$ of the arable land has been re-transformed into untilled land. Also, systems of shelterbelts, i.e. coherent rows of trees that slow down surface winds, were planted over more than 440000 ha in all the natural zones of the Ukraine (Larionov et al., 1997). However, the privatisation process in Ukraine has not re- lieved the pressure of intense agricultural use on the ecosystem (USAID, 2001).

It appears, at this date, uncertain whether the desertification trends will continue, and how climate change might change the properties of the soil and the future frequency and intensity of dust activation. The IPCC report from 2007 mentions "increased drought in some mid-latitude and semiarid low-latitude areas", as well as an increased intensity of "floods, droughts, and erosion" as a result of the predicted climate change over the coming decades (Schneider et al., 2007). Desertification trends, however, will depend in a complex manner on changes in water and wind circulation, as well as further economic and societal changes in the midterm future. Consequently, there remains a considerable degree of uncertainty about the role of dust activation on future air quality, even in relatively distant areas like Central Europe.

\subsection{Health effects}

It is believed, but little researched, that increased dust storm activity has an impact on human health. Natural inorganic dust particles have traditionally been viewed as nonthreatening to human health after inhalation, and soil dust consisting mainly of crystalline rock has been rated less toxic compared for instance to anthropogenic soot (Taylor, 2002). However, Schenker (2000) suggest that inorganic agricultural dusts might explain some of the increase in chronic bronchitis reported in occupational studies among farmers. Wiggs et al. (2003) found a link between increased dust exposure and respiratory health in the Autonomous Republic of Karakalpakstan, Uzbekistan, a region which bears similar desertification trends like Southern Ukraine. It is evident that more research is needed to understand the consequences of increasing dust emissions on the health of the populations inside and outside the source regions.

\section{Conclusions}

A comprehensive body of in situ and remote sensing aerosol measurements was used to depict the advection of an unusual dust plume into Central Europe on 24 March 2007. Hourly $\mathrm{PM}_{10}$ mass concentrations reached $1400 \mu \mathrm{g} \mathrm{m}^{-3}$ in Slovakia and $1200 \mu \mathrm{g} \mathrm{m}^{-3}$ in Poland. The maximum hourly value in Germany was $640 \mu \mathrm{g} \mathrm{m}^{-3}$, where rural $\mathrm{PM}_{10}$ levels are typically around $20 \mu \mathrm{g} \mathrm{m}^{-3}$. As a result of the dust event the legal daily limit value of $\mathrm{PM}_{10}$ (EU First Air Quality Daughter Directive (1999/30/EC)) was exceeded over an area spanning several EU member states.

Rather than through lofted aerosol layers, as often the case with African dust, the coarse dust entered into Central Europe within a well mixed but vertically confined boundary layer. Satellite images, back trajectory calculations as well as meteorological status reports gave evidence that the southern 
Ukraine (district of Kherson, around the Kakhovka Reservoir) was the source region of the dust plume. Owing to the meteorological dipole constellation of low pressure over the Balkans and high pressure over Central Russia, wind gusts up to $30 \mathrm{~m} \mathrm{~s}^{-1}$ were generated over Southern Ukraine and could activate large amounts of soil dust - on the order of $60 \mathrm{Gg}$, from a dry and largely unvegetated surface.

$\mathrm{PM}_{10}$ measurement data from 360 government monitoring stations across Central Europe served as a powerful tool to illustrate the advancement and the spatial extent of the dust plume. Lidar observations over Leipzig, Germany revealed that the high aerosol mass concentrations were confined to a homogeneous boundary layer of about $1.8 \mathrm{~km}$ height. The wavelength dependence of light extinction measurement using both lidar and sun photometer with an Ångström exponent of 0.46 suggested dominating amounts of coarse particles during the main event. Relatively high volume extinction coefficients of $300-400 \mathrm{Mm}^{-1}$ (typical background values $80-90 \mathrm{Mm}^{-1}$ ) and an aerosol optical depth of 0.71 (typical background value 0.1 ) were observed at the wavelength $0.532 \mu \mathrm{m}$. In-situ particle size distributions confirmed the presence of a dominating coarse particle mode with mode diameter $>2 \mu \mathrm{m}$ in the dust plume whereas multiple point measurements in Saxony, Germany demonstrated the homogeneous distribution of particle mass, number, as well as bulk chemical composition across a few $100 \mathrm{~km}$. Independent approaches came to the conclusion that the mass fraction of crustal material in daily average $\mathrm{PM}_{10}$ was about $80 \%$ on 24 March. Based on the observed aerosol characteristics as well as $\mathrm{CO}_{2}$ and $\mathrm{CO}$ measurements, a significant confounding impact of biomass burning on the dust aerosol can be ruled out. Further meteorological transport considerations make any larger contribution of Saharan dust unlikely.

A screening of the long-term time series of $\mathrm{PM}_{10}$ at Melpitz showed that between 1993 and 2007 no event comparable to the dust plume of 24 March 2007 occurred. It appears that the transport of extreme PM concentrations from the Ukraine into Central Europe is an infrequent meteorological phenomenon, which probably does not occur more often than once in 10 years.

Questions and concerns, however, have remained whether such events of dust activation might become more frequent in the future as a result of continuing anthropogenic desertification processes. Natural vegetation growth, cultivation patterns, and even meteorological transport pathways are vulnerable to predicted climate change. An assessment of the role of dust in future climates will therefore require a more thorough understanding of the controlling factors of dust emission, including the role of changes in land use, such as the continuing destruction of soil crusts and removal of vegetation in semi-arid regions. In any case, our observation highlights the need to improve the description of largescale dust emission fluxes under a changing climate as well as direct anthropogenic intervention, and models simulating 3-dimensional transport of coarse dust.

\section{Appendix A}

\section{Charge correction of TDMPS mobility distributions using APS data}

A combination of an electromobility spectrometer (TDMPS) and an aerodynamic particle sizer (APS) was deployed to measure particle size distributions at Melpitz across a wide size range between $3 \mathrm{~nm}$ and $10 \mu \mathrm{m}$. The TDMPS is a custom-built instrument based on Hauke differential mobility analysers that measures particles up to electromobility diameters of $800 \mathrm{~nm}$ (Birmili et al., 1999). The aerodynamic particle sizer (APS; model 3321, TSI Inc., St Paul, USA) (Peters and Leith, 2003), in contrast, measures particles above an aerodynamic diameter of $835 \mathrm{~nm}$. Aerodynamic and electromobility diameters are connected by the so-called "effective particle density", a lump parameter that describes the combined effects of particle material density as well as shape on aerosol motion (Schmid et al., 2007). To evaluate the TDMPS size distributions, the solution of a multiple charge inversion algorithm is necessary (Hagen and Alofs, 1983). The procedure used here involves solving a system of linear equations connecting particle mobility and size and was described in Stratmann and Wiedensohler (1996).

As long as particles larger than the upper size limit of the TDMPS are not removed physically, the multiple charge inversion requires either the knowledge of the size distribution of larger particles, or the assumption that the concentration of larger particles decreases so strongly with particle size that their contributions on smaller electromobility diameters become negligible. As the number concentrations of particles $>800 \mathrm{~nm}$ were available from APS measurements, their effect could accurately be accounted for. In practice, we first used an effective particle density of $2.0 \mathrm{~g} \mathrm{~cm}^{-3}$ (Maring et al., 2003), corresponding to soil dust, to convert the aerodynamic diameters of the APS to electromobility diameters. Then, the contributions of multiply charged particles in APS size channels onto mobility diameters lower than $800 \mathrm{~nm}$ were calculated and subtracted from the TDMPS raw mobility spectrum. Here, we used the bipolar charge distribution according to Wiedensohler (1988) and accounted for multiple charges up to $n=15$, which includes more than $99 \%$ of the total of the multiply charged particles. The corrected TDMPS raw spectrum was then inverted.

Figure A1 shows the inverted TDMPS particle size distributions as a function of mobility diameter with and without correction for particles $>800 \mathrm{~nm}$. Two main effects are evident: First, the correction procedure reduces the TDMPS size distributions at the upper end by relative values up to $40 \%$, which advocates the necessity of the correction scheme. Second, the TDMPS and APS size distributions appear to match better in the overlap region of both instruments after applying the correction. This demonstrates the need to take particles beyond the upper size cut of the TDMPS into account if large amounts of coarse aerosol particles are present. For 

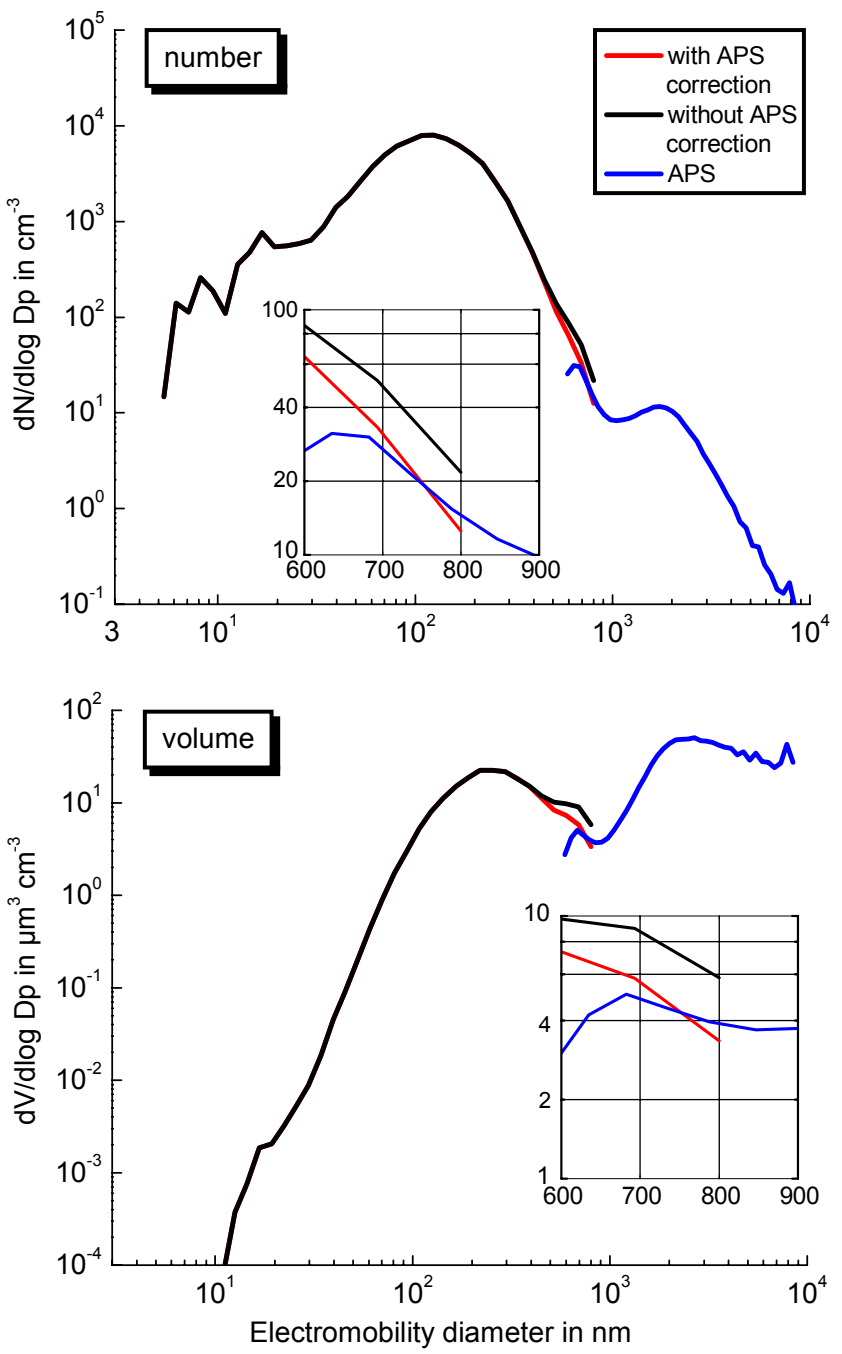

Fig. A1. TDMPS number size distributions with and without correction for multiple charges of particles > $800 \mathrm{~nm}$ (24 March 2007; 11:15-12:15 CET). The overlap region is highlighted for clarity. The lower graph shows volume size distributions assuming spherical particles.

periods without high concentrations of coarse particles, however, the effects of the correction procedure were below $0.5 \%$ on the TDMPS concentrations at the upper end. Under average conditions, TDMPS size distributions can be safely inverted without considering the concentrations of coarse particles.

Acknowledgements. We greatly acknowledge the originators of the $\mathrm{PM}_{10}$ mass concentration data, without whom the spatial description of the dust event would not have been possible. R. Otto prepared several figures of the manuscript. We acknowledge the AERONET team for instrument calibration and data analysis. The Moderate Resolution Imaging Spectroradiometer (MODIS) project contributed the composite image made on board of the Aqua satellite. K. Weinhold was responsible for the maintenance and processing of TDMPS and SMPS measurements at Niesky and
Schwartenberg. In situ measurements in Saxony were supported the Umweltbundesamt (German federal environment agency, Dessau, Germany) and the Sächsisches Landesamt für Umwelt und Geologie (Saxonian Office for the Environment and Geology, Dresden). Measurements at Melpitz and the data evaluation for this paper were conducted within the European Integrated project on Aerosol Cloud Climate and Air Quality Interactions (EUCAARI), coordinated by M. Kulmala, University of Helsinki, Finland. We finally thank three anonymous reviewers who helped improve this manuscript.

Edited by: A. Stohl

\section{References}

Ackerman, S. A.: Remote sensing aerosols using satellite infrared observations, J. Geophys. Res, 102, 17 069-17 079, 1997.

Allen, G., Sioutas, C., Koutrakis, P., et al.: Evaluation of the TEOM method for measurement of ambient particulate mass in urban areas, J. Air Waste Manage. Assoc., 47, 682-689, 1997.

Alpert, P., Kishcha, P., Shtivelman, A., Krichak, S. O., and Joseph, J. H.: Vertical distribution of Saharan dust based on 2.5-year model predictions, Atmos. Res., 70, 109-130, 2004.

Althausen, D., Engelmann, R., Foster, R., Rhone, P., and Baars, H.: Portable Raman lidar for determination of particle backscatter and extinction coefficients, in: Reviewed and revised papers presented at the 22nd ILRC, edited by: Pappalardo, G. and Amodeo, A., vol. 1 of ESA SP-561, pp. 83-86, ESTEC, Noordwijk, The Netherlands, ESA Publications Division, 2004.

Amiridis, V., Balis, D. S., Kazadzis, S., et al.: Four-year aerosol observations with a Raman lidar at Thessaloniki, Greece, in the framework of European Aerosol Research Lidar Network (EARLINET), J. Geophys. Res., 110, D21203, doi:2005JD006190, 2005.

Ångström, A.: Techniques of determining the turbidity of the atmosphere, Tellus, 13, 214-223, 1961.

Annesi-Maesano, I., Forastiere, F., Künzli, N., and Brunekreef, B.: Particulate matter, science and EU policy, Eur. Respir. J., 29, 428-431, 2007.

Ansmann, A. and Müller, D.: Lidar and atmospheric aerosol particles, in: LIDAR - Range-resolved optical remote sensing of the atmosphere, edited by: Weitkamp, C., pp. 105-141, Springer, New York, 2005.

Ansmann, A., Bösenberg, J., Chaikovsky, A., et al.: Long-range transport of Saharan dust to northern Europe: The 11-16 October 2001 outbreak observed with EARLINET, J. Geophys. Res., 108, D04783, doi:2003JD003757, 2003.

Barkan, J., Alpert, P., Kutiel, H., and Kishcha, P.: Synoptics of dust transportation days from Africa toward Italy and central Europe, J. Geophys. Res., 110, D08201, doi:2004JD005222, 2005.

Belnap, J. and Gillette, D. A.: Disturbance of biological soil crusts: Impacts on potential wind erodibility of sandy desert soils in Southeastern Utah, Land Degrad. Devel., 8, 355-362, 1997.

Birmili, W., Stratmann, F., and Wiedensohler, A.: Design of a DMA-based size spectrometer for a large particle size range and stable operation, J. Aerosol Sci., 30, 549-553, 1999.

Birmili, W., Wiedensohler, A., Heintzenberg, J., and Lehmann, K.: Atmospheric particle number size distributions in Central Eu- 
rope: Statistical relations to air masses and meteorology, J. Geophys. Res., 106, 32 005-32 018, 2001.

Bonasoni, P., Cristofanelli, P., Calzolari, F., et al.: Aerosol-ozone correlations during dust transport episodes, Atmos. Chem. Phys., 4, 1201-1215, 2004,

http://www.atmos-chem-phys.net/4/1201/2004/.

Brindley, H. E. and Russell, J. E.: Improving GERB scene identification using SEVIRI: Infrared dust detection strategy, Remote Sens. Environ., 104, 426-446, 2006.

Brüggemann, E. and Rolle, W.: Changes of some components of precipitation in East Germany after the unification, Water Air Soil Poll., 107, 1-23, 1998.

Charron, A., Harrison, R. M., and Quincey, P.: What are the sources and conditions responsible for exceedences of the $24 \mathrm{~h}$ PM10 limit value $\left(50 \mu \mathrm{g} \mathrm{m}^{-3}\right)$ at a heavily trafficked London site?, Atmos. Environ., 41, 1960-1975, 2007.

DIN: Water quality - Determination of 33 elements by inductively coupled plasma atomic emission spectroscopy. Guideline DIN EN ISO 11885, Deutsches Institut für Normung, Berlin, April 1998.

Dolgilevich, M. J.: Extent and severity of wind erosion in the Ukraine, in: International Symposium on Wind Erosion, Kansas State University, Manhattan, KA, USA, 3-5 June 1997.

Donk, S. J. V. and Skidmore, E. L.: Measurement and simulation of wind erosion, roughness degradation and residue decomposition on an agricultural field, Earth Surface Processes and Landforms, 28, 1243-1258, 2003.

Engler, C., Rose, D., Wehner, B., et al.: Size distributions of nonvolatile particle residuals $\left(\mathrm{D}_{p}<800 \mathrm{~nm}\right)$ at a rural site in Germany and relation to air mass origin, Atmos. Chem. Phys., 7, 5785-5802, 2007, http://www.atmos-chem-phys.net/7/5785/2007/.

Escudero, M., Querol, X., Ávila, A., and Cuevas, E.: Origin of the exceedances of the European daily PM limit value in regional background areas of Spain, Atmos. Environ., 41, 730-744, 2007.

Fernandez-Espinosa, A. J., Rodriguez, M. T., de la Rosa, F. J. B., and Sanchez, J. C. J.: A chemical speciation of trace metals for fine urban particles, Atmos. Environ., 36, 773-780, 2002.

Formenti, P. Elbert,, W., Maenhaut, W., et al.: Inorganic and carbonaceous aerosols during the Southern African Regional Science Initiative (SAFARI 2000) experiment: Chemical characteristics, physical properties, and emission data for smoke from African biomass burning, J. Geophys. Res., 108, 8488, doi:2002JD002408, 2003.

Gillette, D. A.: A wind tunnel simulation of the erosion of soil: effect of soil texture, sandblasting, wind speed and soil consolidation on dust production, Atmos. Environ., 12, 1735-1743, 1978.

Gillette, D. A. and Chen, W. A.: Particle production and aeolian transport from a "supply-limited" source area in the Chihuahuan desert, New Mexico, United States, J. Geophys. Res., 106, 52675278, 2001.

Goudie, A. S. and Middleton, N. J.: Saharan dust storms: nature and consequences, Earth Sci. Rev., 56, 179-204, 2001.

Grover, B. D., Eatough, N. L., Eatough, D. J., et al.: Measurement of both nonvolatile and semi-volatile fractions of fine particulate matter in Fresno, CA, Aerosol Sci. Technol., 40, 811-826, 2006.

Hagen, D. E. and Alofs, D. J.: Linear inversion method to obtain aerosol size distributions from measurements with a differential mobility analyzer, Aerosol Sci. Technol., 2, 465-475, 1983.
Hagen, L. J.: Evaluation of the wind erosion prediction system (WEPS) erosion submodel on cropland fields, Environ. Modell. Softw., 19, 171-176, 2004.

Harrison, S. P., Kohfeld, K. E., Roelandt, C., and Claquin, T.: The role of dust in climate changes today, at the last glacial maximum and in the future, Earth Sci. Rev., 54, 43-80, 2001.

Haywood, J. M., Francis, P. N., Glew, M. D., and Taylor, J. P.: Optical properties and direct radiative effect of Saharan dust: A case study of two Saharan dust outbreaks using aircraft data, J. Geophys. Res., 106, 18 417-18 430, 2001.

Hildemann, L. M., Russel, A. G., and Cass, G. R.: Ammonia and nitric acid concentrations in equilibrium with atmospheric aerosols: experiment vs. theory, Atmos. Environ., 18, 17371750, 1984.

Holben, B. N., Kaufman, Y. K., Eck, T. F., et al.: AERONET - A federated instrument network and data archive for aerosol characterization, Remote Sens. Environ., 66, 1-16, 1998.

Krueger, B. J., Grassian, V. H., Cowin, J. P., and Laskin, A.: Heterogeneous chemistry of individual mineral dust particles from different dust source regions: The importance of particle mineralogy, Atmos. Environ., 38, 6253-6261, 2004.

Larionov, G. A., Skidmore, E. L., and Kiryukhina, Z. P.: Wind Erosion in Russia: Spreading and Quantitative Assessment, in: International Symposium on Wind Erosion, Kansas State University, Manhattan, KA, USA, 3-5 June 1997.

Lenschow, P., Abraham, H. J., Kutzner, K., et al.: Some ideas about the sources of PM10, Atmos. Environ., 35, S23-S33, 2001.

Loosmore, G. A. and Hunt, J. R.: Dust resuspension without saltation, J. Geophys. Res., 105, 20 663-20 671, 2000.

Macias, E. S. and Husar, R. B.: Atmospheric particulate mass measurement with beta attenuation mass monitor, Environ. Sci. Technol., 10, 904-907, 1976.

Mahowald, N. and Luo, C.: A less dusty future?, Geophys. Res. Lett., 30, 1903, doi:2003GL017880, 2003.

Maring, H., Savoie, D. L., Izaguirre, M. A., Custals, L., and Reid, J. S.: Mineral dust aerosol size distribution change during atmospheric transport, J. Geophys. Res., 108, D08422, doi:2002JD002536, 2003.

Marticorena, B. and Bergametti, G.: Modeling the atmospheric dust cycle: 1. design of a soil-derived dust emission scheme, J. Geophys. Res., 100, 16415-16430, 1995.

Mattis, I., Ansmann, A., Müller, D., Wandinger, U., and Althausen, D.: Dual-wavelength Raman lidar observations of the extinctionto-backscatter ratio of Saharan dust, Geophys. Res. Lett., 29, 1306, doi:2002GL014721, 2002.

Mattis, I., Ansmann, A., Müller, D., Wandinger, U., and Althausen, D.: Multiyear aerosol observations with dual-wavelength Raman lidar in the framework of EARLINET, J. Geophys. Res., 109, D13203, doi:2004JD004600, 2004.

Merchant, C. J., Embury, O., Borgne, P. L., and Bellec, B.: Saharan dust in nighttime thermal imagery: Detection and reduction of related biases in retrieved sea surface temperature, Remote Sens. Environ., 104, 15-30, 2006.

Miller, R. L., Tegen, I., and Perlwitz, J.: Surface radiative forcing by soil dust aerosols and the hydrologic cycle, J. Geophys. Res. Atmos., 109, D04203, doi:2003JD004085, 2004.

Müller, D., Mattis, I., Wandinger, U., et al.: Saharan dust over a Central European EARLINET-AERONET site: Combined observations with raman lidar and sun photometer, J. Geophys. 
Res., 108, D4345, doi:2002JD002918, 2003.

Müller, D., Ansmann, A., Mattis, I., et al.: Aerosol-type-dependent lidar ratios observed with Raman lidar, J. Geophys. Res., 112, D16202, doi:2006JD008292, 2007.

Neusüss, C., Brüggemann, E., and Herrmann, H.: Determination of water-soluble organic ions of size-segregated aerosol particles by capillary zone electrophoresis, in: Proceedings of the EUROTRAC Symposium 1998, edited by: Borrell, P., 1, 639-643, WITPRESS, Southampton, UK, 1999.

Neusüss, C., Wex, H., Birmili, W., et al.: Characterization and parameterization of atmospheric particle number, mass, and chemical size distributions in central Europe during LACE 98 and MINT, J. Geophys. Res., 107, D8127, doi:2001JD000514, 2002.

Nilsson, E. D., Rannik, U., Kulmala, M., Buzorius, G., and O'Dowd, C. D.: Effects of continental boundary layer evolution, convection, turbulence, and entrainment on aerosol formation, Tellus, 53B, 441-461, 2001.

Peters, T. M. and Leith, D.: Concentration measurement and counting efficiency of the aerodynamic particle sizer 3321, J. Aerosol Sci., 34, 627-634, 2003.

Plewka, A., Gnauk, T., Brüggemann, E., Neusüß, C., and Herrmann, H.: Size-resolved aerosol characterisation for a polluted episode at the IfT research station Melpitz in Autumn 1997, J. Atmos. Chem., 48, 131-156, 2004.

Prospero, J. M., Ginoux, P., Torres, O., Nicholson, S. E., and Gill, T. E.: Environmental characterization of global sources of atmospheric soil dust identified with the Nimbus 7 Total Ozone Mapping Spectrometer (TOMS) absorbing aerosol product, Rev. Geophys., 40, 1002, doi:2000RG000095, 2002.

Putaud, J.-P., Raes, F., Dingenen, R. V., et al.: A European aerosol phenomenology - 1: chemical characteristics of particulate matter at kerbside, urban, rural and background sites in Europe, Atmos. Environ., 38, 2579-2595, 2004.

Pye, K.: Aeolian dust and dust deposition, Academic Press, London, 1987.

Reid, E. A., Reid, J. S., Meier, M. M., et al.: Characterization of African dust transported to Puerto Rico by individual particle and size segregated bulk analysis, J. Geophys. Res., 108, D8591, doi:2002JD002935, 2003

Reimer, E. and Scherer, B..: An operational meteorological diagnostic system for regional air pollution analysis and long-term modelling, Air Poll. Modelling and its Applications IX., Plenum Press, New York, 1992.

Satheesh, S. K. and Moorthy, K.: Radiative effects of natural aerosols: A review, Atmos. Environ., 39, 2089-2110, 2005.

Schenker M.: Exposures and health effects from inorganic agricultural dusts, Env. Health Persp. 108, Suppl 4, 661-664, 2000.

Schepanski, K., Tegen, I., Laurent, B., Heinold, B., and Macke, A.: A new Saharan dust source activation frequency map derived from MSG-SEVIRI IR-channels, Geophys. Res. Lett., 34, L18803, doi:2007GL030168, 2007.

Schneider, S. H., Semenov, S., Patwardhan, A., et al.: Assessing key vulnerabilities and the risk from climate change, in: Climate Change 2007: Impacts, Adaptation and Vulnerability, Contribution of Working Group II to the Fourth Assessment Report of the Intergovernmental Panel on Climate Change (IPCC), edited by: Parry, M. L., Canziani, O. F., Palutikof, J. P., et al., Cambridge University Press, Cambridge, UK, 779-810, 2007.

Schmetz, J., Pili, P., Themkes, S., et al.: An introduction to Me- teosat Second Generation (MSG), B. Am. Meteorol. Soc., 83, pp. 977, 2002.

Schmid, O., Karg, E., Hagen, D. E., Whitefield, P. D., and Ferron, G. A.: On the effective density of non-spherical particles as derived from combined measurements of aerodynamic and mobility equivalent size, J. Aerosol Sci., 38, 431-443, 2007.

Shao, Y.: Physics and Modelling of Wind Erosion, Kluwer Academic Publishers, Dordrecht, The Netherlands, 2000.

Shao, Y., Raupach, M. R., and Findlater, P. A.: Effect of saltation bombardment on the entrainment of dust by wind, J. Geophys. Res., 98, 12 719-12 726, 1993.

Sokolik, I. N.: The spectral radiative signature of wind-blown mineral dust: Implications for remote sensing in the thermal IR region, Geophys. Res. Lett., 29, 2154, doi:2002GL015910, 2002.

Sokolik, I. N., Winker, D. M., Bergametti, G., et al.: Introduction to special section: Outstanding problems in quantifying the radiative impacts of mineral dust, J. Geophys. Res., 106, 18015 $18027,2001$.

Solomon, S., Qin, D., Manning, M., et al. (Eds.): Climate Change 2007: The Physical Science Basis. Contribution of Working Group I to the Fourth Assessment Report of the Intergovernmental Panel on Climate Change (IPCC), Cambridge Univ. Press, Cambridge, United Kingdom, 2007.

Spindler, G., Müller, K., Brüggemann, E., Gnauk, T., and Herrmann, H.: Long-term size-segregated characterization of PM10, PM2.5, and PM1 at the IfT research station Melpitz downwind of Leipzig (Germany) using high and low-volume filter samplers, Atmos. Environ., 38, 5333-5347, 2004.

Stratmann, F. and Wiedensohler, A.: A New Data Inversion Algorithm for DMPS Measurements, J. Aerosol Sci., 27, Suppl. 1, S339-S340, 1996.

Taylor, S. R. and McLennan, S. M.: The Continental Crust: Its Composition and Evolution, Blackwell Science, Oxford, UK, 1985.

Taylor, D. A.: Dust in the wind: Env. Health Perspect., 110(2), A80-87, 2002

Tegen, I., Werner, M., Harrison, S. P., and Kohfeld, K. E.: Relative importance of climate and land use in determining present and future global soil dust emission, Geophys. Res. Lett., 31, L05105, doi:2003GL019216, 2004.

Textor, C., Schulz, M., Guibert, S., et al.: Analysis and quantification of the diversities of aerosol life cycles within AeroCom, Atmos. Chem. Phys., 6, 1777-1813, 2006, http://www.atmos-chem-phys.net/6/1777/2006/.

USAID: Biodiversity Assessment for Ukraine: Task Order under the Biodiversity and Sustainable Forestry IQC (BIOFOR), August 2001, USAID/Kiev, Kiev, Ukraine, 2001.

Vautard, R., Bessagnet, B., Chin, M., and Menut, L.: On the contribution of natural Aeolian sources to particulate matter concentrations in Europe: Testing hypotheses with a modelling approach, Atmos. Environ., 39, 3291-3303, 2005.

VDI: Measurement of soot (ambient air) - thermographical determination of elemental carbon after thermal desorption of organic carbon. Guideline VDI 2465, part 2, Verein Deutscher Ingenieure, Düsseldorf, May 1999.

Wald, A. E., Kaufmann, Y. J., Tané, D., and Gao, B.-C.: Daytime and nighttime detection of mineral dust over desert using infrared spectral contrast, J. Geophys. Res., 103, 32 307-32 313, 1998.

Wang, Y., Zhuang, G. S., Tang, A. H., et al.: The evolution of chem- 
ical components of aerosols at five monitoring sites of China during dust storms, Atmos. Environ., 41, 1091-1106, 2007.

Wiedensohler, A.: An approximation of the bipolar charge distribution for particles in the submicron range, J. Aerosol Sci., 19, 387-389, 1988.

Wiggs, G. F. S., O'Hara, S. L., Wegerdt, J., et al.: The dynamics and characteristics of Aeolian dust in dryland Central Asia: possible impacts on human exposure and respiratory health in the Aral Sea basin, Geograph. J., 169, 142-157, 2003.

Woodward, S., Roberts, D. L., and Betts, R. A.: A simulation of the effect of climate change-induced desertification on mineral dust aerosol, Geophys. Res. Lett., 32, L18810, doi:2005GL023482, 2005.
Wurzler, S., Reisin, T. G., and Levin, Z.: Modification of mineral dust particles by cloud processing and subsequent effects on drop size distributions. J. Geophys. Res., 105, 4501-4512, 2000.

Zender, C., Miller, R., and Tegen, I.: Quantifying mineral dust mass budgets: Systematic terminology, constraints, and current estimates, EOS, 85, 509-512, 2004. 